\title{
Patterns of coastal eddy circulation and abundance of pelagic juvenile fish in the Santa Barbara Channel, California, USA
}

\author{
Mary M. Nishimoto ${ }^{1, *}$, Libe Washburn ${ }^{2}$ \\ ${ }^{1}$ Marine Science Institute, and ${ }^{2}$ Institute for Computational Earth System Science and Department of Geography, \\ University of California, Santa Barbara, California 93106, USA
}

\begin{abstract}
Annual midwater trawling surveys (sampling at depths of 20 to $40 \mathrm{~m}$ ) in early summer 1998 and 1999 revealed strong interannual variability in the patterns of abundance of late-stage larval and juvenile fishes in the Santa Barbara Channel. In June 1998, sampling revealed high concentrations of fishes in the center of a cyclonic eddy in the western Channel corresponding to the lowest dynamic height in the study area. In contrast, eddy circulation was not consistent during the second survey in June 1999, and high concentrations of fishes were not observed. Patterns of evolving surface currents, observed by high frequency radar and concurrent CTD sampling during the trawling surveys, suggest that interannual variability in fish abundance within the Santa Barbara Channel resulted from local retention in 1998, but not in 1999. Time series of relative vorticity (a measure of eddy rotation) computed from surface current fields indicates that the cyclonic eddy observed during the 1998 survey was a stable, persistent feature developing about 6 wk before the trawling surveys. We speculate that the closed circulation of the eddy in 1998 retained larval and juvenile fishes from about late April until late June. In 1999, trains of smaller eddies propagated across the region beginning in mid-May, lasting through the survey period. Given their size and circulation strength, the propagating eddies probably disrupted the closed circulation in the western Channel. These observations indicate a strong link between coastal mesoscale flows and spatial abundance patterns of juvenile and late-stage larval fishes.
\end{abstract}

KEY WORDS: Cyclonic eddy · Retention - Sebastes spp. $\cdot$ Merluccius productus $\cdot$ Myctophidae · Leuroglossus stilbius · California Current

\section{INTRODUCTION}

Natural fluctuations in many marine populations often result from changes in recruitment, defined here as the addition of an incoming year-class. Many temperate and tropical nearshore fishes have planktonic phases lasting weeks or months in their early life histories (Brothers et al. 1983, Moser \& Boehlert 1991). Mortality during this period is high and variable. Typically, less than one percent of the offspring survive through metamorphosis to settle in nursery or adult habitats (Cushing 1974, Chambers \& Trippel 1997).

*E-mail: nishimot@lifesci.ucsb.edu
Small changes in per capita mortality during early development can have a disproportionate effect on the size of the recruiting year-class. Because of this variability, juvenile abundance appears to be a better predictor of recruitment than larval abundance (Sissenwine 1984, Peterman et al. 1988, Bradford 1992, Ralston \& Howard 1995).

Ocean dynamics directly and indirectly affect the spatial and temporal variability of egg and larval mortality. Storms, for example, disperse larvae and destroy food patches (Lasker 1981, Peterman \& Bradford 1987), and persistent wind-induced upwelling or anomalous currents along a coast can advect larvae to unsuitable areas where growth and survivorship can be low or where returning to nearshore settlement habitat is 
unlikely (Hjort 1914, Parrish et al. 1981). At greater temporal and spatial scales, climatic events alter water mass distributions, water column structure, current patterns, and coastal upwelling of nutrient-rich water (McGowan et al. 1998). These environmental perturbations affect movement, spawning, and recruitment patterns of fish populations (McFarlane et al. 2000). El Niño events are linked to delayed and reduced phytoplankton productivity, reduced zooplankton biomass, and increased mortality of coastal fishes during their planktonic larval phase (Lenarz et al. 1995, McGowan et al. 1998, Kahru \& Mitchell 2000). A growing body of evidence suggests that large-scale physical processes producing mortality in the early pelagic phase of fishes and other marine organisms can be offset by smallerscale mechanisms (Connolly \& Roughgarden 1999, Mullin et al. 2000). For example, coastal eddies, mesoscale features inherent in temporally and spatially variable current fields, can retain fishes during their pelagic phase and may enhance recruitment (Owen 1980, Vastano et al. 1992, Hare \& Cowen 1996, Sakuma \& Ralston 1997, Sanchez \& Gil 2000).

Few surveys have targeted the later pelagic stages due to sampling difficulties, such as the size and complexity of the gear required to sample the less abundant and patchily distributed juveniles (e.g. Berry \& Perkins 1963). Fewer surveys have resolved coastal mesoscale physical processes in relation to the distribution of late-stage larvae and pelagic juvenile fishes (Dickey-Collas et al. 1997, Limouzy-Paris et al. 1997). Although they are not typically designed to resolve mesoscale physical processes, some large scale surveys have shown that increased spatial variability of late-stage larvae and pelagic juvenile catches is associated with eddy fields detected post hoc in physical oceanographic data and satellite imagery (Sakuma \& Ralston 1995, 1997, Hare \& Cowen 1996, Sanchez \& Gil 2000, Logerwell \& Smith 2001). In this study, we investigated the relationship between populations of latestage larval and juvenile fishes and the mesoscale flow field in and around the Santa Barbara Channel, a part of the larger California Current System.

The California Current System (CCS) is the eastern boundary current system of the North Pacific (Hickey 1998). Eddies, filaments, and meanders driven by variable winds and pressure gradients characterize the flow field over the shelf and offshore in the equatorward-flowing jet of the CCS (e.g. Strub et al. 1991). These mesoscale features result in part from headlands and bathymetry along the coast (Kelly 1985). Our study area, the Santa Barbara Channel, is a transition region between the strong coastal upwelling regime extending northward from Point Conception to Washington and the warmer waters of the Southern California Bight.
The circulation in the western Santa Barbara Channel consists primarily of a cyclonic flow that is strongest spring through fall and weakest or absent in winter (Dever et al. 1998, Harms \& Winant 1998, Winant et al. 1999). A poleward, temperature-dependent pressure gradient tends to drive strong westward currents in the Channel. Opposing the pressure gradient are winds that tend to induce upwelling and drive eastward flow, especially in the southern Channel. When effects of wind and pressure gradients balance, the flow is cyclonic with westward flow along the northern boundary of the Channel and eastward flow along the Channel Islands, the southern boundary. Currents in the upper layers carry a diversity of fish species into the Santa Barbara Channel where many recruit to adult habitats (Love et al. 1999).

We found variations in abundance patterns of small pelagic fishes collected during midwater trawling surveys in early summer 1998 and 1999 consistent with differences in the evolving mesoscale flow field in the Santa Barbara Channel region. In this paper, we focus on the most abundant and ubiquitous fishes sampled: three midwater fish species, California smoothtongue Leuroglossus stilbius (family Bathylagidae), northern lampfish Stenobrachius leucopsarus (Myctophidae), Mexican lampfish Triphoturus mexicanus (Myctophidae); a cod-like species, Pacific hake Merluccius productus (Merlucciidae);and a species complex of rockfishes Sebastes spp. (Scorpaenidae). Of particular interest are the latter 2 taxa, which were represented by late-stage larvae and pelagic juveniles. From an ecological perspective, these small fishes of about 15 to $100 \mathrm{~mm}$ standard length (SL) in our surveys are important forage for seabirds, marine mammals, piscivorous fishes including salmon, and other marine life (Ainley et al. 1996). We examined the hypothesis that interannual abundance variations were linked to flow patterns that produced significant retention of fishes in 1998, but not in 1999. Our findings indicate that eddy circulation, when persistent, retains small fishes within a local area. While we could not conclusively prove a linkage between high abundance and this mechanism of retention, lines of evidence from several data sources were consistent with this interpretation.

\section{MATERIALS AND METHODS}

Shipboard surveys in 1998 and 1999 began in early June and included midwater trawling and vertical profiling of water properties at stations throughout the Santa Barbara Channel and adjacent waters to the north and south (sampling region shown in Fig. 1; survey maps in Figs. 3 \& 5). Fishes were sampled at night to minimize net avoidance (Sakuma et al. 1999). We 
typically made 4 net hauls between 2100 and 0500 PST using a modified Cobb mid-water trawl with a nominal $12.2 \times 12.2 \mathrm{~m}$ opening and a $9 \mathrm{~mm}$ mesh codend. During each haul, a fixed length of wire was payed out and the net was towed for $15 \mathrm{~min}$ at $\sim 5 \mathrm{~km} \mathrm{~h}^{-1}$ covering $1.4 \pm 0.2 \mathrm{~km}$. A time-depth recorder attached to the headrope (rope across the top of the net opening) provided trawling depth every minute. The histogram of Fig. 2 shows the distribution of headrope depth sampled every minute for all tows in 1998 ( $\mathrm{n}=$ 41), and Fig. 3 shows the trawling stations. The modal depth bin was centered on $20 \mathrm{~m}$. The mean headrope depth was $20 \pm 2 \mathrm{~m}$ (SD). In 1999, net depth data were collected only during the first 2 survey nights; and mean headrope depth was $26 \pm 1 \mathrm{~m}$ for 7 hauls. Acoustic measurements have shown that the area of the opening of a net changes with trawling depth, and based on the measurements by Lenarz et al. (1991), we estimate that the opening was $10 \mathrm{~m}$ wide and $14 \mathrm{~m}$ high when trawling at a headrope depth of $20 \mathrm{~m}$, so the corresponding water volume sampled per haul was $\sim 2 \times 10^{5} \mathrm{~m}^{3}$.

Vertical profiles of water properties were obtained using a conductivitytemperature-depth (CTD) profiler (SBE-19, SeaBird Electronics) immediately before or after each net haul so we could associate patterns of larval fish abundance with local hydrographic conditions. The CTD was lowered to $200 \mathrm{~m}$, or to about $10 \mathrm{~m}$ above the bottom at shallow stations. Some casts were obtained at stations without net hauls to augment coverage of the study area. During casts, temperature, conductivity, and pressure were sampled at $2 \mathrm{~Hz}$ and then averaged into $1 \mathrm{~m}$ depth bins during subsequent processing. Salinity $\mathrm{S}$, potential temperature $\theta$, potential density anomaly $\sigma_{\theta}$ and dynamic height $\phi$ (at 5 dbar relative to a 200 dbar reference pressure) were computed from the $1 \mathrm{~m}$ averages of conductivity, temperature, and pressure.

We directed sampling for fishes and water properties based upon satellite

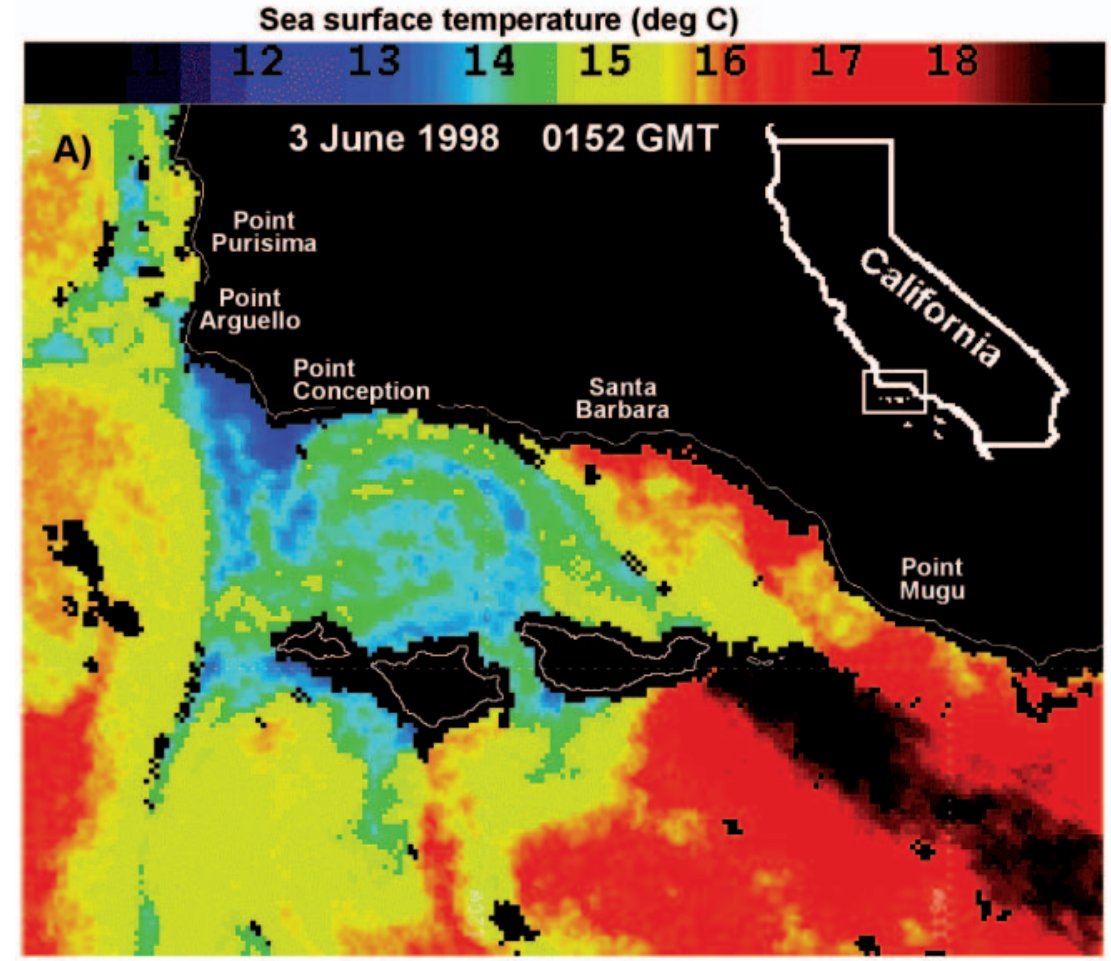

2 June 19981900 GMT

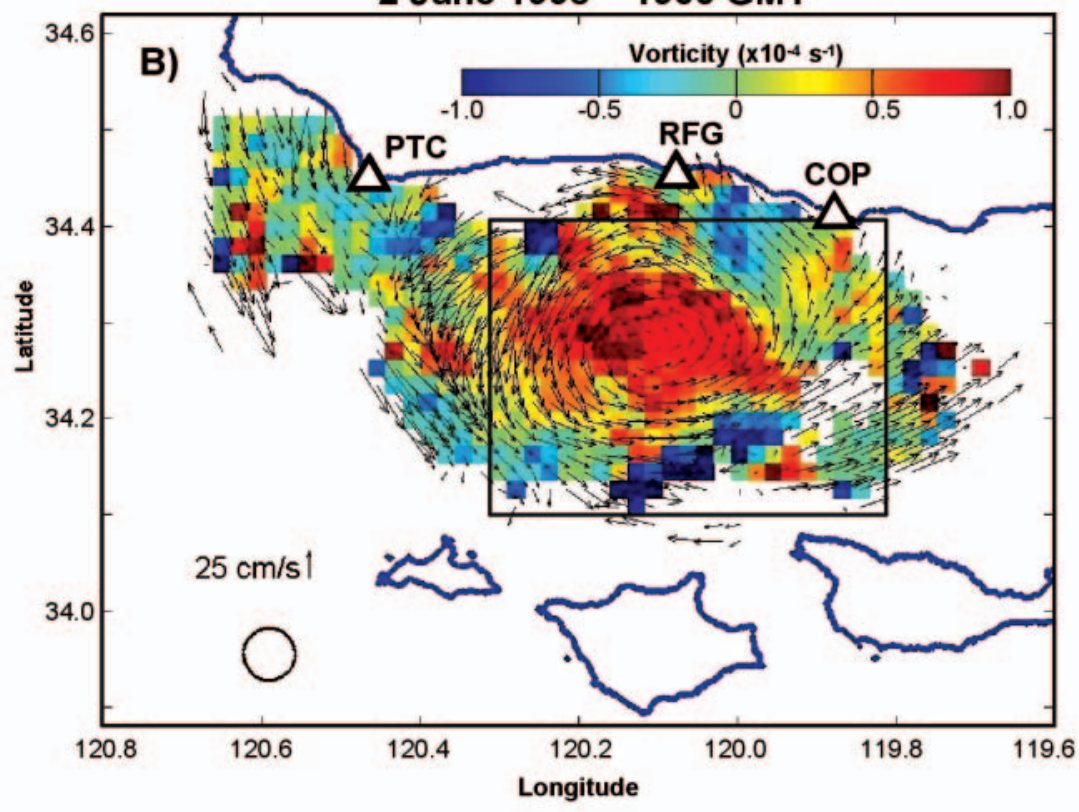

Fig. 1. Eddy circulation in the study area. (A) Satellite sea surface temperature image at 01:52 h GMT on 3 June 1998 shows a cyclonic eddy visualized by curving temperatures features in the western Santa Barbara Channel. (B) Spatial pattern of surface currents at 19:00 h GMT on 2 June 1998 showing a strong cyclonic eddy. Color scale indicates magnitude of relative vorticity $\zeta$. The highest rotation rates occurred in the eddy center. Evolving surface currents were mapped with high frequency radars at Coal Oil Point (COP), Refugio (RFG), and Point Conception (PTC). Box indicates area over which $\zeta$ was averaged to produce the time series of Figs. $7 \& 11$. Scale for current speed is at lower left. Circle (radius $=3 \mathrm{~km}$ ) at lower left is the area over which current vectors were averaged 


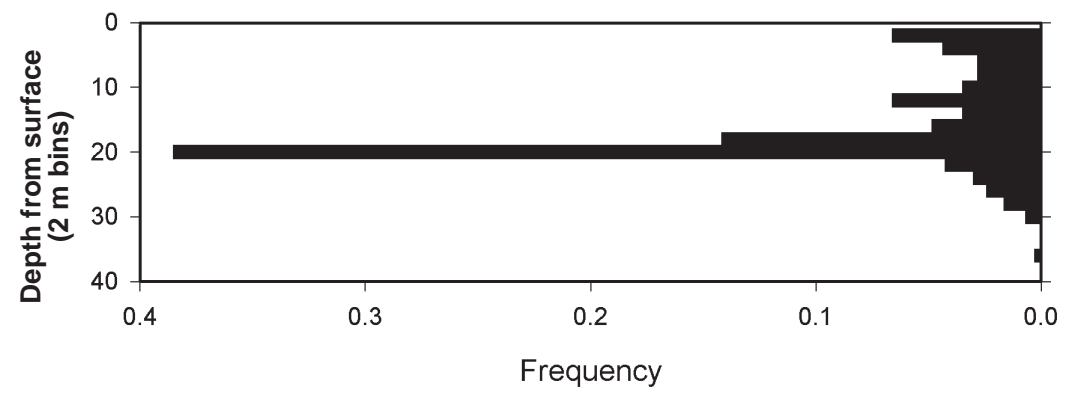

Fig. 2. Frequency distribution of headrope depths (position of the top of the net, sampled once per min) from all net tows of 1998 survey $(n=41)$. The net opening extended $14 \mathrm{~m}$ below the headrope depth

sea surface temperature (SST) images and surface current maps from an array of three high frequency (HF) radars located along the mainland coast. Neither the satellite imagery nor the HF radar velocity could be accessed from the research vessel, but daily communication with shore-based personnel provided descriptions of sea surface currents and SST patterns based on images such as shown in Fig. 1.

Maps of surface currents in the western Santa Barbara Channel were produced hourly. The HF radars operated at frequencies around $12 \mathrm{MHz}$ and were deployed at Point Conception, Refugio, and Coal Oil Point (triangles in Fig. 1B). HF radars measure coastal currents in the upper $\sim 1 \mathrm{~m}$ of the water column using a Doppler radar technique (e.g. Barrick \& Lipa 1998). Two or more radars with overlapping coverage measure the total velocity vector field of surface currents in the overlap area. The radars were configured to have a range of $42 \mathrm{~km}$, a radial resolution of $1.5 \mathrm{~km}$, and azimuthal resolution of $5^{\circ}$. Surface velocity vectors were located on a square grid with points separated by $2 \mathrm{~km}$. Every hour, all radial vectors within a $3 \mathrm{~km}$ radius of each grid point were fitted to north and east velocity components using the least-square technique of Gurgel (1994). The circle in the lower left hand corner of Fig. 1B shows the scale of this spatial averaging compared with the radar coverage area. Our processing of radial current vectors to form surface current maps is the same as that used by Paduan \& Rosenfeld (1996). B. M. Emery, L. Washburn and J. Harlan (unpubl.) found significant correlation between radial currents measured with these HF radars and those measured by an array of moored current meters in the study area. Graber et al. (1997) and Shay et al. (1998) provide a comprehensive discussion of the errors and expected differences between moored current measurements and HF radars.

Generally, all fishes from each haul were sorted, identified, enumerated, and most were frozen. In the June 1998 survey, several hauls with extremely large catches of fishes and zooplankton required representative subsampling, and subsamples of known volume were sorted and abundances were estimated from the total volume of the haul. When a species or species complex was very abundant in a sorted sample, the fish were counted and 100 fish of one species or $1000 \mathrm{ml}$ of a species complex were retained for inspection in the laboratory. However, all rockfishes (Sebastes spp.) sorted from a sample or subsample were retained. In the laboratory, fishes were identified to species level or to a higher taxonomic level when species could not be determined based on meristics, morphology, and pigment pattern, or due to damage.

A number of rockfish species were collected during the surveys. Only 5 species of rockfishes present in the samples, shortbelly rockfish Sebastes jordani, bocaccio $S$. paucispinis, cowcod S. levis, chilipepper S. goodei, and blackgill rockfish $S$. melanostomus, could be identified with confidence as both late-stage larvae and pelagic juveniles. These species are described in Moser (1996), and all except for shortbelly rockfish were rare in the samples. Two species, squarespot rockfish $S$. hopkinsi and halfbanded rockfish $S$. semicinctus were abundant as pelagic juveniles; but identification of the late-stage larvae and transforming juveniles of these species was problematic. Given these limitations, we chose to group all rockfish species as a complex, Sebastes spp.

In post-survey analysis, the hauls were grouped according to the spatial distribution of $\phi$ and geographic position of the stations. Contour maps of $\phi$ and vertical cross-sections of $\mathrm{S}, \theta$, and $\sigma_{\theta}$ were created using Surfer (Golden Software 1999) with a Kriging algorithm. We used SPSS for Windows to carry out statistical procedures (SPSS 1999). ANOVA was employed to test for differences in catches among defined groups of stations. Abundance data (ind. haul $^{-1}$ ) was $\log (x+1)$ transformed to reduce heteroscedacity. We used the Levene test to evaluate the equality of variances among groups $(p<0.01)$. If ANOVA determined that differences existed among the means, we used either the Tukey test or Tamhane $\mathrm{T} 2$ test to determine which means differed. The Tamhane T2 test, a conservative pairwise comparisons test based on a $t$-test, is appropriate when the variances are unequal. The Tukey test is appropriate when variances are equal. The independent samples $t$-test, generating a $t$ statistic that is based on either equal or unequal variances, was used for between-year comparisons. A significance level $\alpha=0.05$ was assigned for the ANOVA, pairwise comparison tests, and $t$-test. 


\section{RESULTS}

\section{Concentrated abundance of fishes in a persistent mesoscale eddy in June 1998}

At the beginning of the juvenile fish survey on 2 June 1998 the surface circulation was strongly cyclonic (Fig. 1B), consistent with previous observations of the summer flow field in the western Santa Barbara Channel (e.g. Harms \& Winant 1998), and water flow was dominated by an eddy centered at $120.1^{\circ} \mathrm{W}$ and $34.3^{\circ} \mathrm{N}$ with a diameter of about $30 \mathrm{~km}$. The rotation of the eddy, quantified by its relative vorticity $\zeta$ (equal to twice the angular rotation rate), ranged from $0.2 f$ (rotation period of $\sim 9 \mathrm{~d}$ ) on the periphery to about $0.7 f$ (rotation period of $\sim 3 \mathrm{~d}$ ) in the center, where $f$ is the Coriolis parameter $\left(f^{-1}=21.5 \mathrm{~h}\right)$. We estimated $\zeta$ at each point by using a centered first difference, $\zeta=\Delta \mathrm{v} / \Delta \mathrm{x}-\Delta \mathrm{u} / \Delta \mathrm{y}$, where $\Delta \mathrm{u}, \Delta \mathrm{v}$ are the changes in the northward and eastward components of surface current velocity between 2 grid points, and $\Delta \mathrm{x}, \Delta \mathrm{y}$ are twice the $2 \mathrm{~km}$ grid spacing in the east and north directions. The relatively uniform vorticity (red shading, Fig. 1B) in the center indicated that the core of the eddy was approximately in solid body rotation. Alternating warm and cool streaks wrapped around the eddy, revealed by satellite sea surface temperature (SST) imagery, also indicated strong rotary flow in the eddy (Fig. 1A).

The eddy circulation was not merely a surface flow, but extended well below the surface layer. The spatial pattern of $\phi$ had a minimum in the core of the eddy (Fig. 3A), consistent with the strong cyclonic circulation revealed by the HF radars. We defined the eddy by $\phi \leq 0.37 \mathrm{~m}$ (shaded region, Fig. 3A). Isotherms along an east-west section across the eddy (section location shown in Fig. 3A) rose sharply in the eddy center consistent with the cyclonic rotation (Fig. 4A). For example, the $10^{\circ} \mathrm{C}$ isotherm rose about $80 \mathrm{~m}$ in the center of the section compared with its positions on the ends of the section. Isopleths of $\mathrm{S}$ and $\sigma_{\theta}$ exhibited similar deflections across this section (Fig. 4B, C). The higher salinity in the eddy center extended almost to the surface while cooler water in the center was not evident above about $20 \mathrm{~m}$, possibly due to local solar heating.

Horizontal density gradients in the eddy supported vertical shear in horizontal geostrophic currents: current speed increased by $0.2 \mathrm{~m} \mathrm{~s}^{-1}$ over the $200 \mathrm{~m}$ from the reference level to the sea surface (Fig. 4D). Currents across the section revealed southward flow at depth west of the center and northward flow to the east, such that the deep flow was cyclonic. Deflections of the deepest isopleths in Fig. 4 indicate the cyclonic

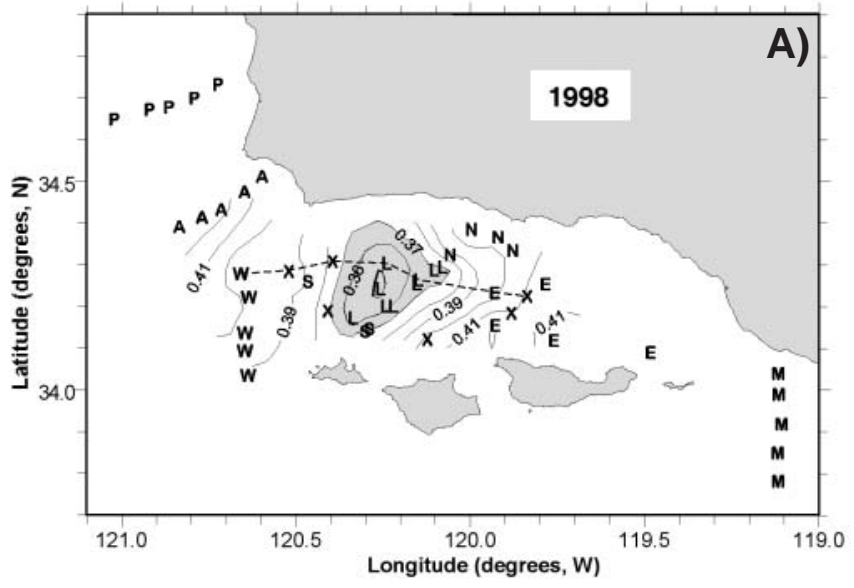

Fig. 3. (A) Distribution of dynamic height $\phi$ at 5 dbar computed with respect to a reference pressure level of 200 dbar. The center of the eddy is indicated by $\phi \leq 0.37 \mathrm{~m}$ (shaded region). Letters indicate groups of trawling locations in the eddy and surrounding waters: $\mathrm{L}$, eddy center; $\mathrm{P}$, Point Purisima; A, Point Arguello; W, west Channel entrance; $\mathrm{S}$, southern and western edge of eddy; $\mathrm{N}$, northeastern edge of eddy; $\mathrm{E}$, eastern edge of eddy and east Channel; and $\mathrm{M}$, Point Mugu. Vertical profiles of water properties were obtained at all trawling locations. $\mathrm{X}$, vertical profiles of water properties only. Dashed line: sections of $\mathrm{T}$, $\mathrm{S}$, and $\sigma_{\theta}$ of Fig. 4. (B) Mean catch per haul $( \pm 1 \mathrm{SE})$ of the 5 dominant fish taxa

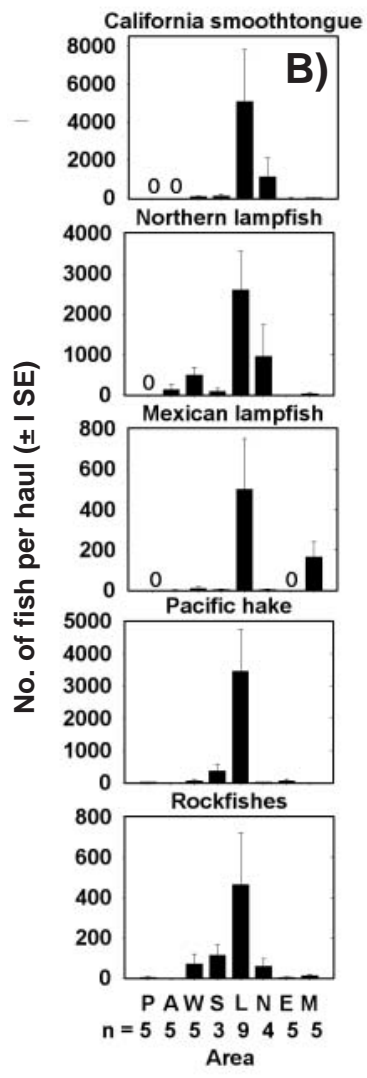

circulation of the eddy extended below $200 \mathrm{~m}$. The nine CTD casts in the area where $\phi \leq 0.37 \mathrm{~m}$ (Fig. 3A) were obtained during the nights of 2, 3, 4, and 9 June 1998 indicating that the eddy persisted at least a week, and time series of relative vorticity obtained from the HF radars showed that the eddy persisted for much longer (see below).

During the 2 wk sampling, 2-15 June 1998, net hauls were conducted in the eddy and surrounding waters to explore possible influences on juvenile fish abundance. Hauls were grouped into 7 geographic areas, 

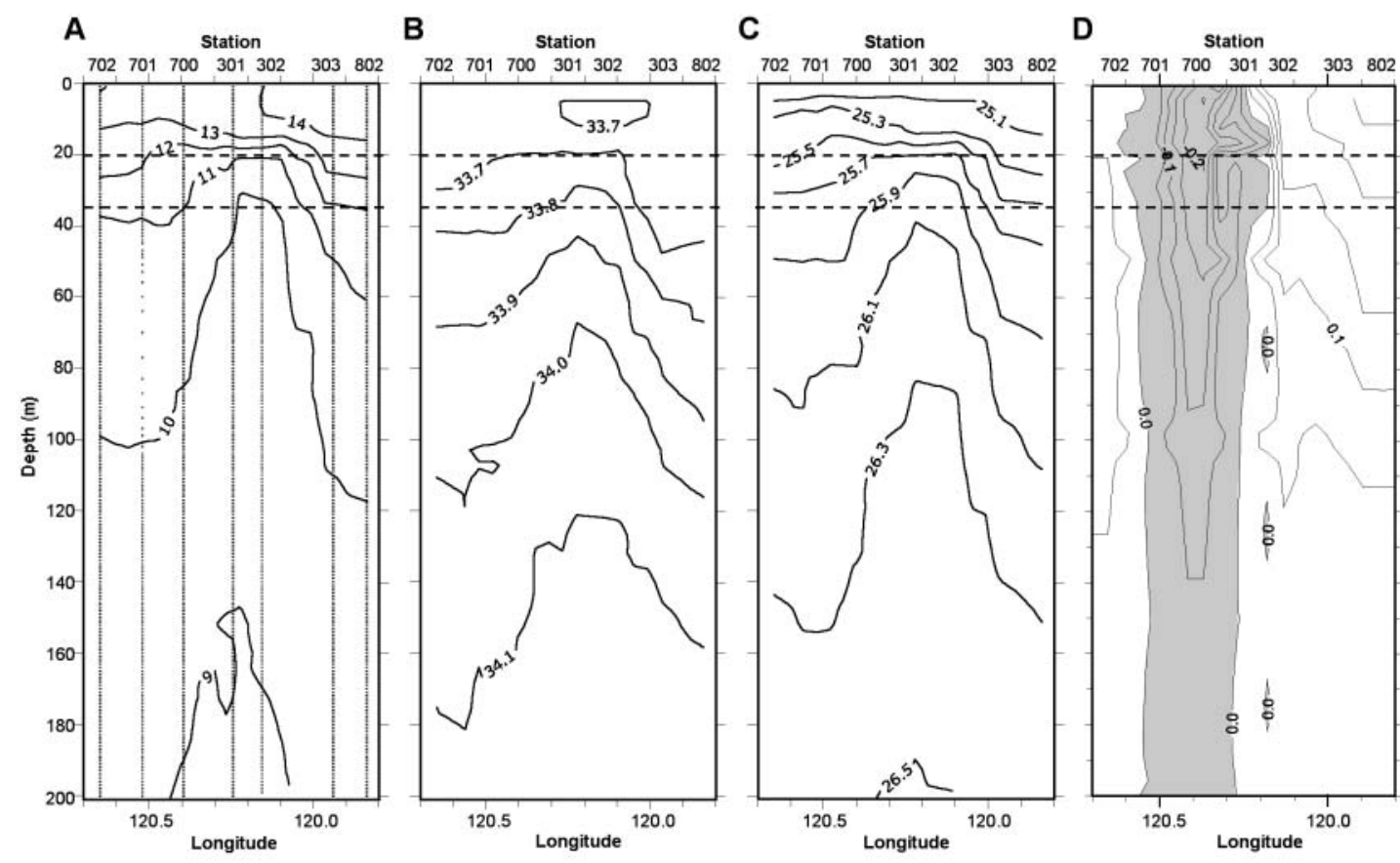

Fig. 4. East-west vertical sections of: (A) potential temperature $\theta\left({ }^{\circ} \mathrm{C}\right)$, (B) salinity, (C) potential density anomaly $\sigma_{\theta}\left(\mathrm{kg} \mathrm{m}^{-3}\right)$, and (D) geostrophic velocity $\left(\mathrm{m} \mathrm{s}^{-1}\right)$ along the section indicated by the line in Fig. 3A. Vertical lines indicate profile locations identified by station numbers along the $x$-axis at the top. Stn 301 and 302 were in the eddy center, defined by dynamic height $\phi \leq 0.37 \mathrm{~m}$. The cyclonic flow of the eddy produced the large uplift of isotherms. Deep cyclonic flow of the eddy was indicated by southward flow (shaded region, panel D) west of the eddy center and northward flow east of the center

Table 1. ANOVA on $1998 \log (x+1)$ transformed data divided into 3 groups: (1) stations to the west and south of the eddy center; (2) inside the eddy; and (3) to the east and north of the eddy center $\left(F_{0.05,2,2,38}=4.08\right)$. Taxa ordered by mean abundance in 1998. A multiple comparison test determined what groups differed as indicated by an inequality with type 1 error probability for individual pairs of groups

\begin{tabular}{|c|c|c|c|c|c|c|}
\hline Taxon & $\begin{array}{l}\text { Source of } \\
\text { variation }\end{array}$ & SS & DF & MS & $F$ & $\begin{array}{l}\text { Tukey }^{1} \text { or } \\
\text { Tamhane }^{2}\end{array}$ \\
\hline $\begin{array}{l}\text { California } \\
\text { smoothtongue }\end{array}$ & $\begin{array}{l}\text { Groups } \\
\text { Error } \\
\text { Total }\end{array}$ & $\begin{array}{l}48.8 \\
31.9 \\
80.7\end{array}$ & $\begin{array}{r}2 \\
38 \\
40\end{array}$ & $\begin{array}{r}24.4 \\
0.8\end{array}$ & 29.1 & $\begin{array}{c}2 \neq 1,3 \\
(p<0.0001)^{1}\end{array}$ \\
\hline Pacific hake & $\begin{array}{l}\text { Groups } \\
\text { Error } \\
\text { Total }\end{array}$ & $\begin{array}{l}33.4 \\
27.1 \\
60.6\end{array}$ & $\begin{array}{r}2 \\
38 \\
40\end{array}$ & $\begin{array}{r}16.7 \\
0.7\end{array}$ & 23.4 & $\begin{array}{c}2 \neq 1,3 \\
(p<0.0001)^{1}\end{array}$ \\
\hline $\begin{array}{l}\text { Northern } \\
\text { lampfish }\end{array}$ & $\begin{array}{l}\text { Groups } \\
\text { Error } \\
\text { Total }\end{array}$ & $\begin{array}{l}29.0 \\
44.6 \\
73.6\end{array}$ & $\begin{array}{r}2 \\
38 \\
40\end{array}$ & $\begin{array}{r}14.5 \\
1.2\end{array}$ & 12.3 & $\begin{array}{c}2 \neq 1,3 \\
(p<0.0001)^{2}\end{array}$ \\
\hline $\begin{array}{l}\text { Mexican } \\
\text { lampfish }\end{array}$ & $\begin{array}{l}\text { Groups } \\
\text { Error } \\
\text { Total }\end{array}$ & $\begin{array}{l}22.7 \\
20.1 \\
42.7\end{array}$ & $\begin{array}{r}2 \\
38 \\
40\end{array}$ & $\begin{array}{r}11.3 \\
0.5\end{array}$ & 21.5 & $\begin{array}{c}2 \neq 1,3 \\
(p<0.0002)^{1}\end{array}$ \\
\hline Rockfishes & $\begin{array}{l}\text { Groups } \\
\text { Error } \\
\text { Total }\end{array}$ & $\begin{array}{l}14.1 \\
20.7 \\
34.8\end{array}$ & $\begin{array}{c}2 \\
38 \\
40\end{array}$ & $\begin{array}{l}7.0 \\
0.5\end{array}$ & 12.9 & $\begin{array}{c}2 \neq 1,3 \\
(p<0.0002)^{1}\end{array}$ \\
\hline Other fishes & $\begin{array}{l}\text { Groups } \\
\text { Error } \\
\text { Total }\end{array}$ & $\begin{array}{r}0.4 \\
9.7 \\
10.2\end{array}$ & $\begin{array}{c}2 \\
38 \\
40\end{array}$ & $\begin{array}{l}0.2 \\
0.3\end{array}$ & 0.9 & \\
\hline
\end{tabular}

including the eddy center (defined by $\phi \leq 0.37 \mathrm{~m})$. Mean abundances of 4 of the 5 dominant taxa in the eddy exceeded those found outside of the Channel north of Pt. Conception (Pts. Purisima and Arguello) and off Pt. Mugu by at least an order of magnitude (Fig. 3B), except for the catch of Mexican lampfish, which was about a third of that in the eddy center, reflecting its southerly distribution loosely bounded at Pt. Conception (Moser et al. 1993). Pacific hake and rockfishes were represented by late-stage larvae and pelagic juveniles. Pacific hake catches ranged from 142 to 11063 fish haul ${ }^{-1}$ in the eddy center, 12 to 750 at the eddy periphery, and 0 to 146 in the east Channel and areas outside of the Channel combined. Rockfish catches in the same areas ranged from 39 to 2434,1 to 197 , and 0 to 265 fish haul $^{-1}$, respectively. The midwater fishes, represented by specimens $\geq 1$ yr old, were absent from some areas; none of the 3 midwater species (California smoothtongue, northern lampfish, Mexican lampfish) were collected off Pt. Purisima (Fig. 3B). Given 
this and the disproportionately large number of samples collected in the eddy center, we combined areas and divided the midwater trawling stations into 3 groups for the ANOVA: eddy center (stations labeled L in Fig. 3A, n =9); west and south of the eddy center (A, P, W, and $S_{;} n=18$ ); and north and east of the eddy center $\left(\mathrm{N}, \mathrm{E}\right.$, and $\left.\mathrm{M}_{i} \mathrm{n}=14\right)$.

ANOVA determined that the catch of each of the 5 taxa differed among the groups of stations (Table 1). The pairwise multiple comparison tests showed that the 5 taxa were concentrated in the eddy center, and their abundances were significantly lower in the 2 areas outside of the eddy $(p<0.0002)$. These 2 outer areas did not significantly differ from one another for any of the 5 taxa $(\mathrm{p}>0.200)$.

Overall, the midwater species and Pacific hake dominated the survey catches in 1998. California smoothtongue, northern lampfish, and Mexican lampfish comprised $39.8,24.3$, and $4.2 \%$ of the mean total catch, respectively. Mostly fish older than $1 \mathrm{yr}$ represented these midwater species. Pacific hake and rockfishes represented by late-stage larvae and pelagic juveniles comprised 25.2 and $4.0 \%$ of the mean total catch, respectively. These 5 taxa comprised $97.5 \%$ of the mean total catch. The remaining $2.5 \%$ was dominated by northern anchovy Engraulis mordax, and sanddabs Citharichthys sordidus and $C$. stigmaeus.

\section{Dispersed fish abundance patterns and variable mesoscale flows in June 1999}

Compared with 1998, conditions in the Channel and surrounding waters were much different in June 1999, when stronger winds and cooler water temperatures prevailed (Hayward et al. 1999). Because of the higher wind speeds, completion of the surveys in 1999 took all of June to complete, 2 wk longer than in 1998. In the post-survey analysis, we divided the hydrographic and trawl data into 2 sampling periods. Leg 1 included the first 7 survey nights from 6-21 June 1999 when samples were collected off Point Purisima, within the Channel, and off Point Mugu. We designated the 3 remaining nights from 24-30 June as leg 2 when the Channel was resampled and the area outside of the western entrance of the Channel was sampled for the first time. This allowed us to reconstruct and compare the hydrography and spatial distribution of fishes of 2 synoptic periods bearing in mind that the first leg was a protracted time interval, and that not all areas were re-sampled during leg 2.

Circulation in the Channel was more variable in 1999 compared with the stable cyclonic eddy flow pattern in 1998. During the1999 surveys, the spatial pat-
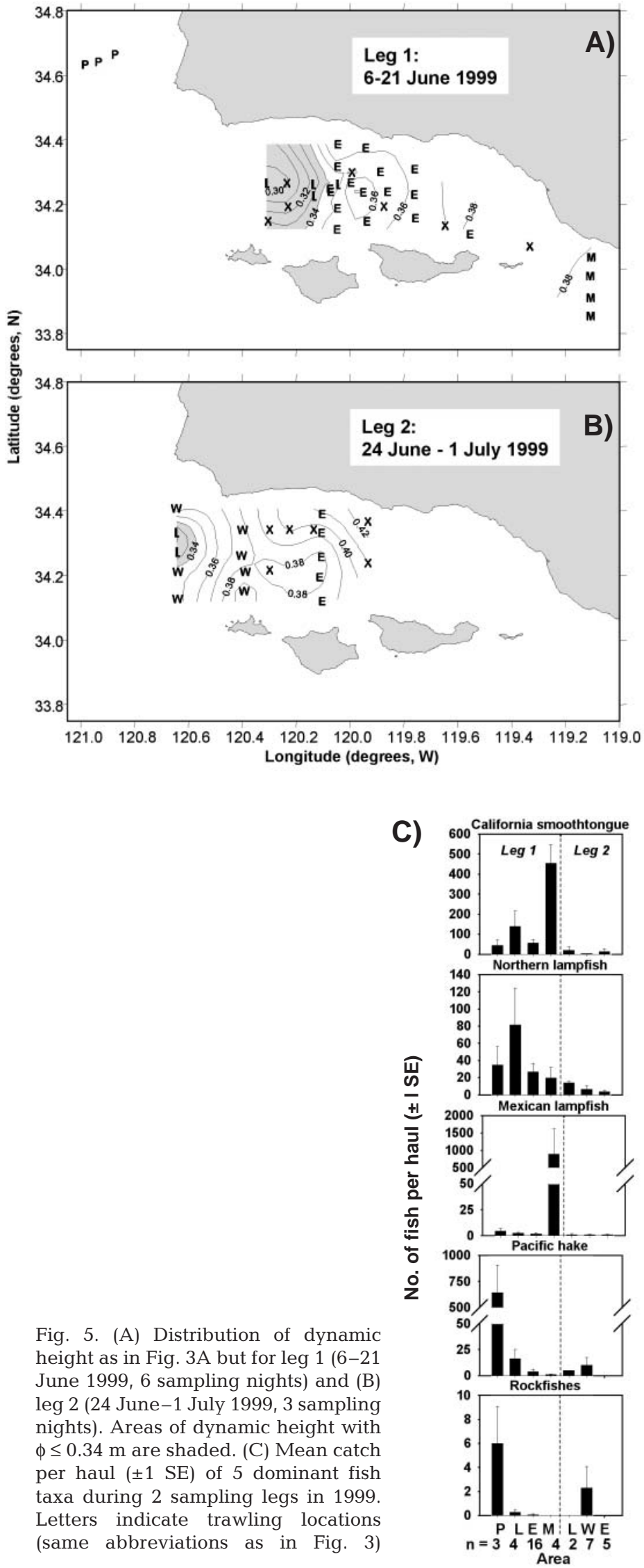

Fig. 5. (A) Distribution of dynamic height as in Fig. 3A but for leg 1 (6-21 June 1999, 6 sampling nights) and (B) leg 2 (24 June-1 July 1999, 3 sampling nights). Areas of dynamic height with $\phi \leq 0.34 \mathrm{~m}$ are shaded. (C) Mean catch per haul $( \pm 1 \mathrm{SE})$ of 5 dominant fish taxa during 2 sampling legs in 1999 Letters indicate trawling locations (same abbreviations as in Fig. 3) 
Table 2. ANOVA on $\log (x+1)$ transformed data from 1999 leg 1 divided into 4 groups: (1) Pt. Purisima; (2) low dynamic height in the western Channel; (3) eastern Channel; and (4) Pt. Mugu areas $\left(F_{0.05,2,3,26}=3.67\right)$. Taxa ordered by mean abundance in 1999 during leg 1. Tukey multiple comparison test determined what groups differed as indicated by an inequality with type 1 error probability for individual pairs of groups

\begin{tabular}{|c|c|c|c|c|c|c|}
\hline Taxon & $\begin{array}{l}\text { Source of } \\
\text { variation }\end{array}$ & SS & $\mathrm{DF}$ & MS & $F$ & Tukey \\
\hline Rockfishes & $\begin{array}{l}\text { Groups } \\
\text { Error } \\
\text { Total }\end{array}$ & $\begin{array}{l}1.5 \\
0.4 \\
1.8\end{array}$ & $\begin{array}{r}3 \\
23 \\
26\end{array}$ & $\begin{array}{l}0.5 \\
0.0\end{array}$ & 31.1 & $\begin{array}{c}1 \neq 2,3,4 \\
(p<0.0001)^{a}\end{array}$ \\
\hline Pacific hake & $\begin{array}{l}\text { Groups } \\
\text { Error } \\
\text { Total }\end{array}$ & $\begin{array}{r}14.8 \\
5.2 \\
20.0\end{array}$ & $\begin{array}{r}3 \\
23 \\
26\end{array}$ & $\begin{array}{l}4.9 \\
0.2\end{array}$ & 22.1 & $\begin{array}{c}1 \neq 2,3,4 \\
(p<0.0001)\end{array}$ \\
\hline $\begin{array}{l}\text { California } \\
\text { smoothtongue }\end{array}$ & $\begin{array}{l}\text { Groups } \\
\text { Error } \\
\text { Total }\end{array}$ & $\begin{array}{r}8.3 \\
19.1 \\
27.5\end{array}$ & $\begin{array}{r}3 \\
23 \\
26\end{array}$ & $\begin{array}{l}2.8 \\
0.8\end{array}$ & 3.3 & \\
\hline $\begin{array}{l}\text { Northern } \\
\text { lampfish }\end{array}$ & $\begin{array}{l}\text { Groups } \\
\text { Error } \\
\text { Total }\end{array}$ & $\begin{array}{r}0.8 \\
15.6 \\
16.4\end{array}$ & $\begin{array}{r}3 \\
23 \\
26\end{array}$ & $\begin{array}{l}0.3 \\
0.7\end{array}$ & 0.4 & \\
\hline $\begin{array}{l}\text { Mexican } \\
\text { lampfish }\end{array}$ & $\begin{array}{l}\text { Groups } \\
\text { Error } \\
\text { Total }\end{array}$ & $\begin{array}{r}10.7 \\
7.6 \\
18.3\end{array}$ & $\begin{array}{r}3 \\
23 \\
26\end{array}$ & $\begin{array}{l}3.6 \\
0.3\end{array}$ & 10.8 & $\begin{array}{c}4 \neq 1,2,3 \\
(p<0.012)\end{array}$ \\
\hline Other fishes & $\begin{array}{l}\text { Groups } \\
\text { Error } \\
\text { Total }\end{array}$ & $\begin{array}{l}4.8 \\
2.8 \\
7.7\end{array}$ & $\begin{array}{r}3 \\
23 \\
26\end{array}$ & $\begin{array}{l}1.6 \\
0.1\end{array}$ & 13.2 & $\begin{array}{c}4 \neq 2,3 \\
(p<0.027)\end{array}$ \\
\hline
\end{tabular}

stations off Pt. Purisima and the catch ranged from 2 to 12 fish haul $^{-1}$. The largest rockfish catch was 13 individuals collected at a station outside of the western entrance of the Channel northwest of San Miguel Island during leg 2. The remaining hauls contained only 1 or no rockfish. Pacific hake exhibited a spatial distribution similar to rockfishes. Largest Pacific hake catches were off Pt. Purisima and ranged from 141 to 1033 fish haul $^{-1}$. The remaining catches ranged from 0 to 7 with only 4 larger catches between 25 and 55 fish haul ${ }^{-1}$. California smoothtongue and Mexican lampfish were most abundant off Pt. Mugu.

Overall, catch abundance in 1999 was lower by an order of magnitude compared to 1998 (Table 3A). The difference between years was striking for pelagic young-of-year rockfishes. The average catch dropped from 128.1 fish haul ${ }^{-1}$ in 1998 to 0.9 in 1999. The eddy where fishes were most abundant in 1998 was repeatedly sampled, so such a comparison is biased. The average catch is reduced 4-fold between years if samples only collected outside of the eddy center in

tern of $\phi$ rapidly evolved as indicated by repeated sampling in the western Channel. Shipboard sampling of leg 1 showed that $\phi$ was low in the Channel north of the San Miguel-Santa Rosa Islands passage (shaded area, Fig. 5A), corresponding to a cyclonic turning of currents observed by HF radar (data not shown). High winds terminated leg 1 sampling on 21 June. Resampling during leg 2 revealed a region of low $\phi$ on the westernmost line, just outside the Channel (shaded area, Fig. 5B). At this time $\phi$ was higher in the Channel north of the San Miguel-Santa Rosa Islands passage than in leg 1.

In contrast to 1998, no consistent pattern of concentration among the dominant taxa was found in the areas of low $\phi$ for either leg (Fig. 5C; note difference in $y$-axis scale compared with Fig. 3B). During leg 1 inside the Channel, California smoothtongue, northern lampfish, and Pacific hake exhibited an increase in abundance in the low $\phi$ area; however, ANOVA and pairwise multiple comparison tests showed that all 5 taxa were most abundant outside of the Channel (Table 2). Late-larval stage and pelagic juvenile rockfishes and Pacific hake were most abundant north of the Channel. Rockfishes were collected at each of the 3
1998 are considered, but this interannual difference remains significant (Table 3B).

The contribution of the principal taxa to the catch changed to some extent between years. Together, the 5 taxa comprised 97.5 and $95.7 \%$ of the total catch in 1998 and 1999, respectively (Table 3A). However, the rank order among the taxa and overall abundance changed. Although the mean catch of Mexican lampfish from all hauls decreased from 1998 to 1999, the contribution of this species to the assemblage increased from $4.2 \%$ in 1998 to $33.8 \%$ in 1999. Young-ofyear Pacific hake and rockfishes were less important in the fish assemblage in 1999. Pacific hake ranking fell from 2nd in 1998 to 4 th in 1999. Rockfishes represented only $0.3 \%$ of the mean total catch in 1999, down from $4.0 \%$ in 1998. The abundance of Pacific sanddab Citharichthys sordidus surpassed that of rockfishes in 1999. The mean catch of late-larval stage and pelagic juvenile stage Pacific sanddab was nearly 8 times greater than that of rockfishes; however, the contribution of Pacific sanddab to the total fish assemblage in $1999(2.6 \%)$ was less than that of rockfishes in 1998, underlining the decline in importance of rockfishes to the species assemblage between years. 


\section{DISCUSSION}

\section{Stable cyclonic eddy in 1998 and local retention}

Over the 6 wk period beginning 1 May 1998 (which included the trawling surveys), the pattern of mean surface currents observed by HF radar was consistent with a stable eddy circulation and closed streamlines (Fig. 6A). Vectors shown in Fig. 6 were obtained from the area of highest coverage by the radars; total vectors were available for at least $80 \%$ of the time over a $3 \mathrm{yr}$ record. The eddy was centered over the deepest part of the Santa Barbara Basin with higher flow speeds in the northwest portion of the eddy, possibly due to higher northwest winds in the western part of the Channel. Current direction approximately followed bathymetric contours around the basin.

To examine the stability of the eddy beyond just the mean flow pattern of Fig. 6A, we computed the time series of spatially averaged relative vorticity $\zeta$ over a large region of the western Channel. To form $\bar{\zeta}$, all values of $\zeta$ within the region outlined by the box in Fig. $7 \mathrm{C}$ were averaged together and plotted as a time series (blue dots, Fig. 7A). The $24 \mathrm{~h}$ running mean of $\zeta$ (red line, Fig. 7A) consistently indicated cyclonic rotation for about $2 \mathrm{mo}$, from late April through late June with $\bar{\zeta}$ fluctuating in the range 0.2 to $0.4 f$. Three representative images during May 1998 of the surface velocity and vorticity fields showed the cyclonic eddy over the Santa Barbara Basin (Fig. 7B-D). During July and August the circulation was much more variable with large excursions in $\bar{\zeta}$ on time scales of a few days. The higher concentrations of fishes observed during the trawling survey (indicated by green vertical lines, Fig. 7A) were consistent with retention by the eddy's stable rotary flow and closed streamlines. It is unlikely, however, that eddy retention in the western Channel could have occurred before late April 1998.

The large scale dynamic height field observed during the CalCOFIsurvey of 2-23 April 1998 showed that strong equatorward (eastward) flow swept through the Channel during part of April 1998, a flow pattern inconsistent with retention. As discussed by Hayward et al. (1999), a low salinity region was positioned near shore during the spring 1998 CalCOFI survey. This jetlike feature is clearly seen by the crowding of lines of dynamic height anomalies north of Point Conception
(Fig. 8). Within the limited spatial resolution of the CalCOFI survey, the pattern of dynamic height anomalies indicated eastward, or equatorward transport through the Channel. Time series of near-surface currents at the western Channel entrance supported this conclusion.

Current meters at $5 \mathrm{~m}$ depth on mooring 'SMIN' (part of an array of recorders deployed by Scripps Institution of Oceanography; location shown in Fig. 10) recorded episodes of equatorward (eastward) currents occasionally exceeding $0.2 \mathrm{~m} \mathrm{~s}^{-1}$ from 20 March to 24 April 1998 (Fig. 9A). Out of these 36 d, equatorward flow occurred at $5 \mathrm{~m}$ depth on $19 \mathrm{~d}$ (shaded areas, Fig. 9A). At $45 \mathrm{~m}$, the pattern was similar but flow speeds were less (data not shown). Equatorward flow, especially during spring and summer, is unusual at 'SMIN' because alongshore pressure differences at a scale larger than the Channel typically force poleward (westward) flow there (Dever et al. 1998, Harms \& Winant 1998, Winant et al. 1999). For the 6 weeks preceding the 1999 survey, the current meter at 'SMIN' recorded only a few brief ( $\sim 1 \mathrm{~d}$ or shorter) episodes of eastward currents (Fig. 9B).

During the equatorward flow episodes at 'SMIN' in 1998, the limited data available from the HF radars for April indicated a broader pattern of equatorward flow. (Hardware problems with the radars resulted in data 

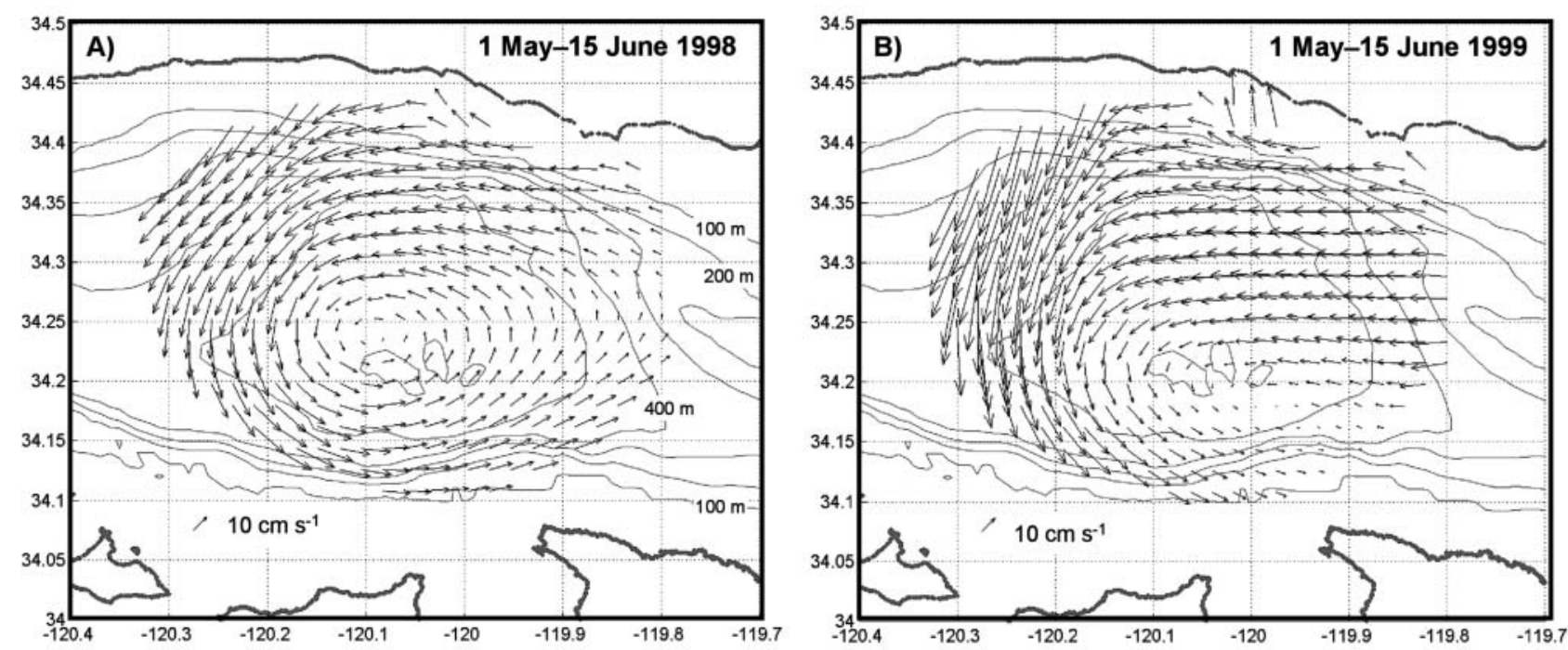

Fig. 6. Mean surface currents in western Santa Barbara Channel from (A) 1 May to 15 June 1998 and (B) 1 May to 15 June 1999. These 6 wk periods included the 1998 and 1999 trawling surveys
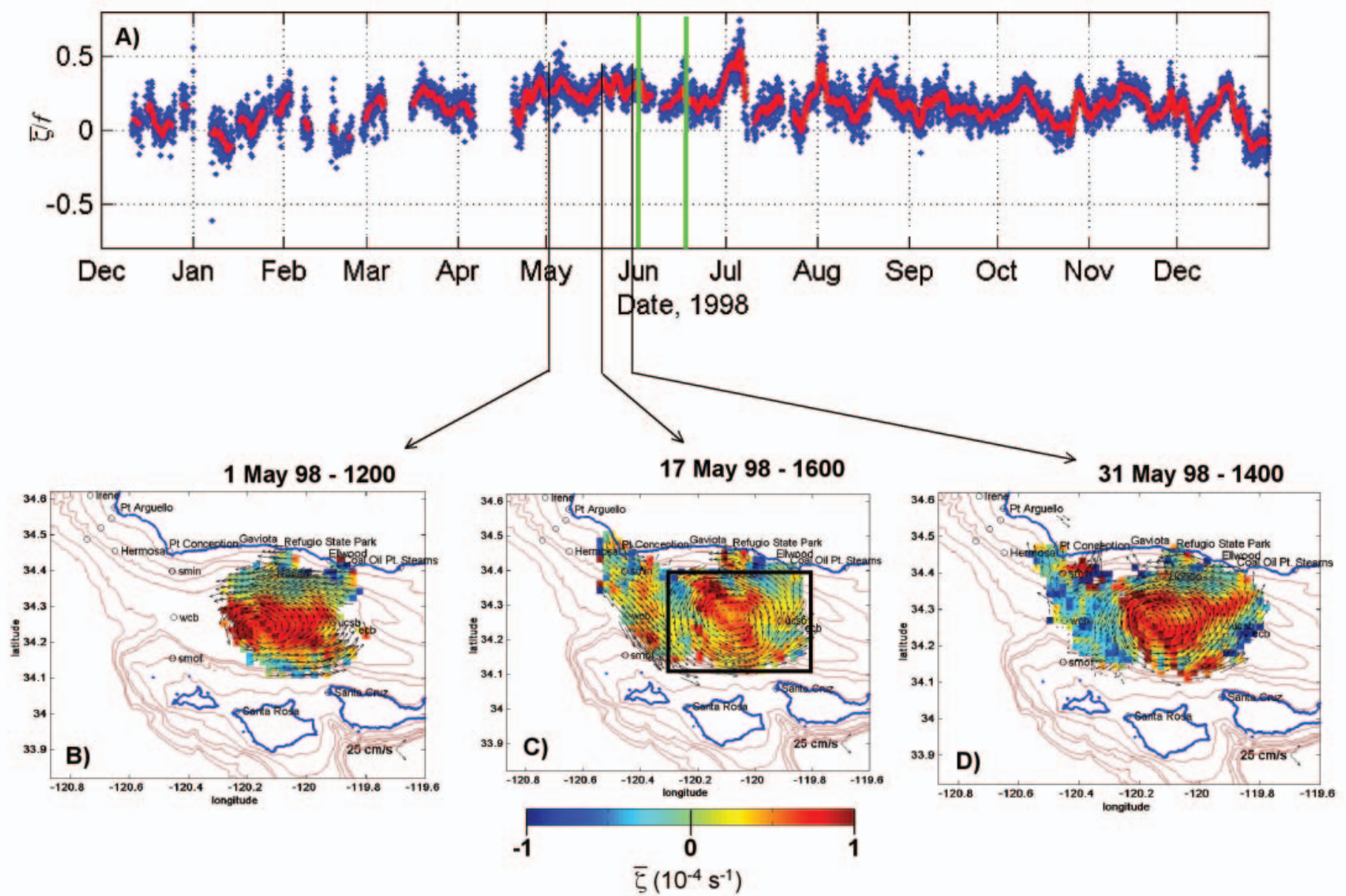

Fig. 7. (A) Time series of spatially averaged relative vorticity $\zeta$, normalized by the Coriolis parameter $f$, in the western Santa Barbara Channel from 1 December 1997 through 31 December 1998. $\bar{\zeta}$ was computed from surface current data obtained by HF radar. The box of panel (C) shows the region over which spatial averages were computed. Blue dots indicate hourly values of $\bar{\zeta} / f$ and the red line is a $36 \mathrm{~h}$ running mean. Positive values indicate cyclonic (counter-clockwise) flow. Vertical green lines indicate the period of the trawling surveys. Surface flow field in the western Channel on (B) 1 May 1998 at 12:00 h GMT, (C) 17 May 1998 at 16:00 h GMT, and (D) 31 May 1998 at 14:00 h GMT. Arrows at lower right are the velocity scale. Color contours show relative vorticity $\zeta$ as indicated on the color scale 
loss for much of April 1998). A $24 \mathrm{~h}$ average of surface currents obtained by the HF radars on 28 March during an equatorward flow episode at SMIN (dashed line, Fig. 9A) showed equatorward flow spanning the Channel entrance. The flow meandered eastward through the western Channel (Fig. 10) around a small cyclonic eddy-like feature, centered at $120.03^{\circ} \mathrm{W}$, $34.27^{\circ} \mathrm{N}$. We speculate that the broad equatorward flow made retention in the western Channel unlikely before late April 1998.

\section{Strongly variable flow in 1999 and no eddy retention}

In contrast to the stable eddy circulation in 1998, highly variable flow prevailed in the weeks before and during the trawling surveys of 1999. The pattern of mean flow over the 6 wk period beginning 1 May 1999 was not eddy-like, but rather was a cyclonic turning of a broad westward flow along the northern Santa Barbara Basin into a southeast flow toward the Channel Islands (Fig. 6B). The turning flow from westward to southward and then to southeastward approximately followed isobaths. This flow pattern with its open streamlines was unlikely to have retained larvae prior to the trawling surveys.

Not only was the flow pattern more open in 1999, it was more variable. Time series showed $\bar{\zeta}$ cycling from near zero to $\sim 0.5 f$ then back to near zero on timescales of 3 to $4 \mathrm{wk}$ beginning in early May and continuing through August (Fig. 11A). These cycles corresponded to strongly changing flow and vorticity patterns as seen in three representative examples from May 1999

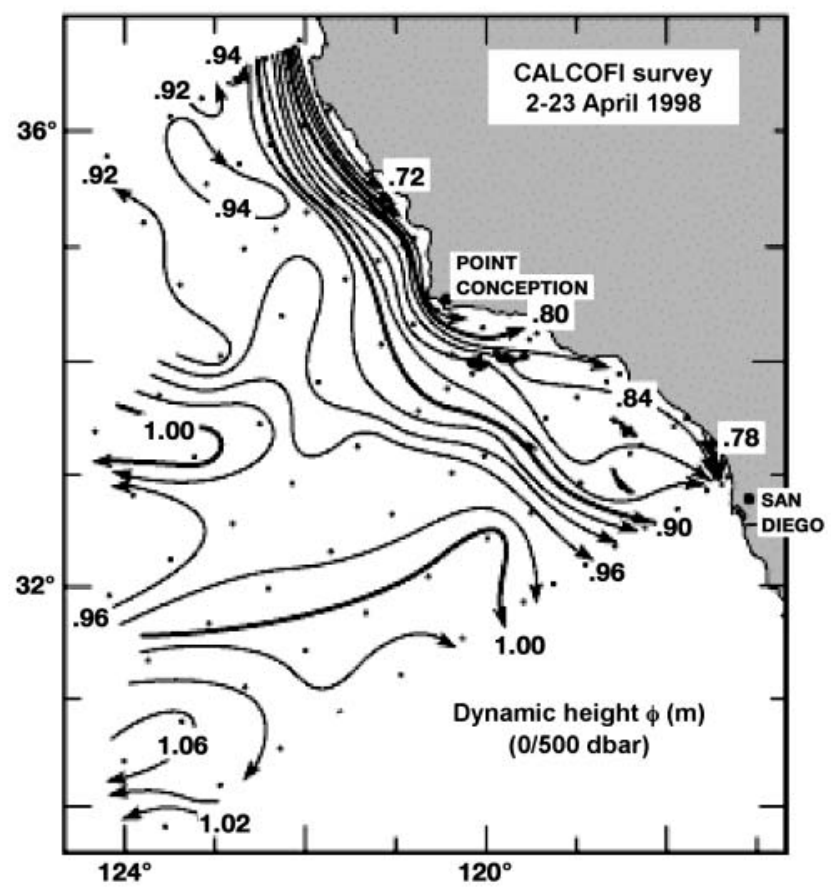

Fig. 8. Dynamic height field from the CalCOFI survey of 2-23 April 1998 adapted from Hayward et al. (1999). Crowding of dynamic height contours shows an equatorward jet near the coast. The pattern indicated strong equatorward (eastward) flow through the Santa Barbara Channel

(Fig. 11B-D). The patterns of Fig. 11D suggested the mechanism for strongly varying $\xi: 2$ eddy-like features visualized as regions of fairly uniform, but opposite vorticity (red and blue regions, Fig. 11D). As reported by Beckenbach et al. (2000) and Washburn et al.
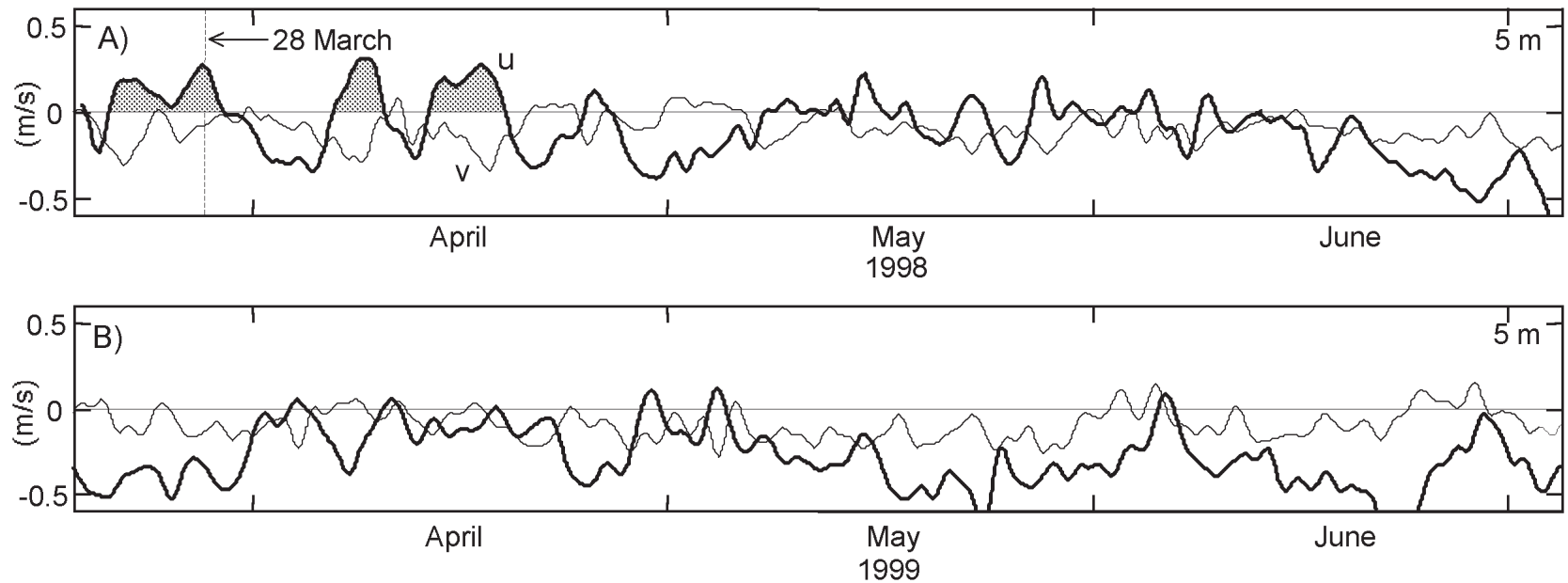

Fig. 9. Current time series at $5 \mathrm{~m}$ depth measured at mooring 'SMIN' from late March through June (A) in 1998 and (B) in 1999. Heavy lines show eastward currents $(\mathrm{u})$, and light lines show northward currents $(\mathrm{v})$. Shaded areas show episodes of sustained strong equatorward flow in March and April. The location of mooring 'SMIN' is indicated by the circle in Figure 10. Note absence of sustained eastward currents in panel (B) 


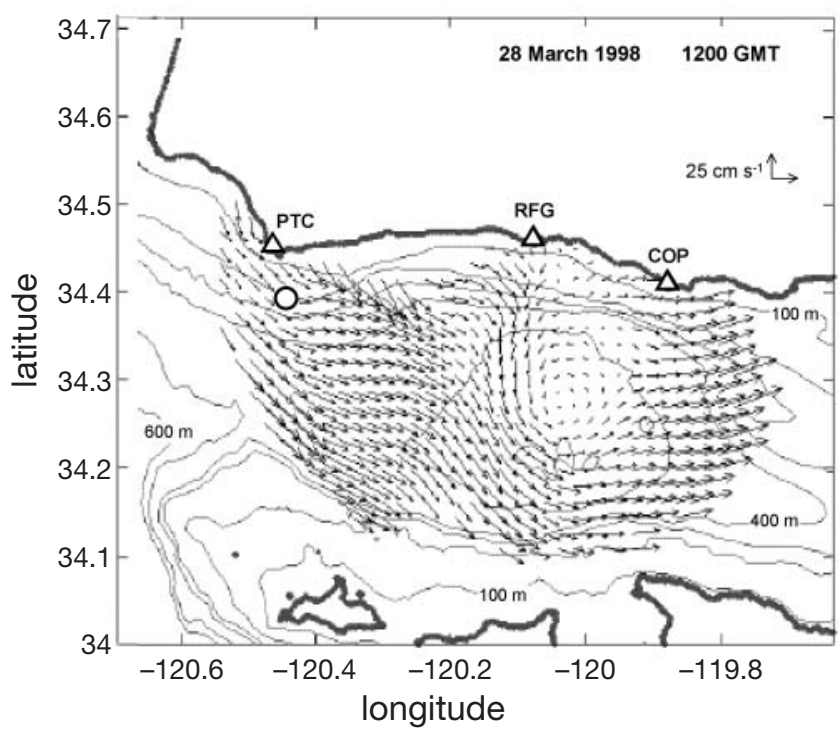

Fig. 10. Spatial distribution of surface currents in the western Santa Barbara Channel on 28 March 1998. Arrows show currents averaged over $24 \mathrm{~h}$. Circle indicates position of mooring 'SMIN'. Time of this image is indicated by dashed line in current time series of Fig. 9A

(2000), these were propagating eddies, rotating in opposite directions and moving westward across the Channel at speeds of about $7 \mathrm{~km} \mathrm{~d}^{-1}$. The propagating eddies occurred in groups or trains lasting up to 2 mo, most commonly in summer, but also in fall. Their passage through the Channel dominated variance in $\bar{\zeta}$

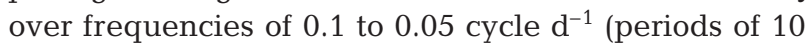
to $20 \mathrm{~d}$ ). Patterns of dynamic height obtained across the propagating eddies suggested they were not just surface features, but extended to at least $200 \mathrm{~m}$ (data not shown). We speculate that these eddies disrupted the larger scale cyclonic circulation in the Channel and prevented larval retention. The propagating eddies were also present in 1998, but did not begin strongly until after the trawling surveys. The prominent peak in $\zeta$ in early July 1998 of Fig. 7A coincided with their onset.

\section{Cyclonic eddies and fish abundance}

Cyclonic eddies modify their physical environment in a number of ways that may account for higher abundance of larval and juvenile (and some adult) fishes within them. Surface current drogues have demonstrated a pattern of cyclonic recirculation in the western Channel on time scales of several days (Dever et al. 1998, Winant et al. 1999). Typical azimuthal current speeds in the persistent eddy observed in 1998 were 0.2 to $0.3 \mathrm{~m} \mathrm{~s}^{-1}$, generally exceeding the sustainable swimming speed of larval and juvenile fishes (Stobutski \& Bellwood 1997). If the fishes exhibited no directed swimming behavior to move radially outward, they would tend to remain in the eddy.

A simple explanation for the higher abundance of fishes in the eddy center is concentration due to uplift of water within the eddy. The cyclonic eddy in the Channel in 1998 was approximately in geostrophic balance (Rossby number $\bar{\zeta} / f \approx 0.3$ in May and June 1998 from Fig. 7A) such that colder, salty, high density water occupied the eddy center due to strong uplift of isopleths of $\theta, \mathrm{S}$, and $\sigma_{\theta}$ in the center (Fig. 4). Assuming for simplicity that fishes were initially distributed uniformly within a range of temperatures before the eddy developed, uplift associated with cyclonic circulation could have compressed isotherms in the eddy center and thus concentrated fishes by vertical advection. This mechanism would increase density proportionately with compression of isothermal surfaces. As shown in Fig. 4A, temperatures in the eddy center within the trawling range of 20 to $35 \mathrm{~m}$ ranged from about 10 to $11^{\circ} \mathrm{C}$. The vertical spacing of the 10 and $11^{\circ} \mathrm{C}$ isotherms was about $10 \mathrm{~m}$ in the high gradient region in the center and about $60 \mathrm{~m}$ on either end of the section, outside the eddy. This suggests that passive uplift in the eddy could have increased concentrations six-fold within the eddy center. This increase is comparable to the abundance increase found for California smoothtongue and northern lampfish (Fig. 3B). In contrast, densities of Pacific hake, rockfishes, and Mexican lampfish increased much more than six-fold in the eddy suggesting passive advection alone did not account for the increases.

We cannot discount the possibility that relatively high densities of fishes occurred at depths where we did not sample; however, concentrations of fish comparable to those found in the eddy feature are not likely in deeper water. Lenarz et al. (1991) and Sakuma \& Ralston (1997) found that pelagic juvenile rockfishes and Pacific hake were most abundant at depths around $30 \mathrm{~m}$ and shallower, based on sampling at 10, 30, and $100 \mathrm{~m}$ depths. Our sampling was centered in the 20 to $35 \mathrm{~m}$ stratum (Fig. 2), but was roughly within the expected center of the distribution of these taxa. It is possible that large concentrations may have occurred near the surface where we did not sample. For example, Lenarz et al. (1991) reported the occurrence of large catches of Pacific hake at $10 \mathrm{~m}$.

Fishes can actively maintain themselves in favorable environments and can be attracted to strong vertical temperature gradients. Uplift of isothermal surfaces due to geostrophic balance, such as we observed in the cyclonic eddy in 1998, has been associated with nutrient enrichment and heightened primary productivity in the euphotic zones of other cyclonic eddies (Hay- 
ward \& Mantyla 1990, Siegel et al. 1999). Zooplankton are concentrated in the cold cores of eddies (Schwing et al. 1991, Huntley et al. 1995, Zimmerman \& Biggs 1999, Kimura et al. 2000), and high densities of larval fish have been associated with the zooplankton concentrations (Kimura et al. 2000). In a cyclonic eddy off central California, euphausiids and copepods were found to be concentrated in the fluorescence maxima at the pycnocline (Huntley et al. 2000). Other studies show concentration of particles at or near the pycnocline (Malkiel et al. 1999). Many larval species are diel vertical migrators as indicated by surveys comparing the day and night vertical distribution patterns of larval fishes (Boehlert et al. 1985, Sakuma et al. 1999). Midwater fishes (California smoothtongue, northern lampfish, and Mexican lampfish), represented by juveniles and adults in the present study, are extensive vertical migrators ascending several 100s of meters to feed in surface waters nightly. These midwater fishes may have been attracted to prey concentrations at the thermocline within the eddy observed in 1998.

Laboratory studies demonstrate that fish can modify or eliminate diel vertical migration patterns in response to one or a combination of environmental factors (e.g. light, temperature, turbidity, food density, presence of predators) and intrinsic factors (e.g. stage of development, hunger, condition) (Neilson \& Perry 1990, Olla et al. 1996). Pacific hake exhibit an ontogenetic shift in their vertical distribution; larvae are most abundant below the mixed layer and juveniles are most abundant in the upper mixed layer during the night off central California (Sakuma \& Ralston 1997). Such a shift is not uncommon; comparable changes with development in the depth distribution of shortbelly rockfish and other rockfishes have also been observed (Lenarz et al. 1991).
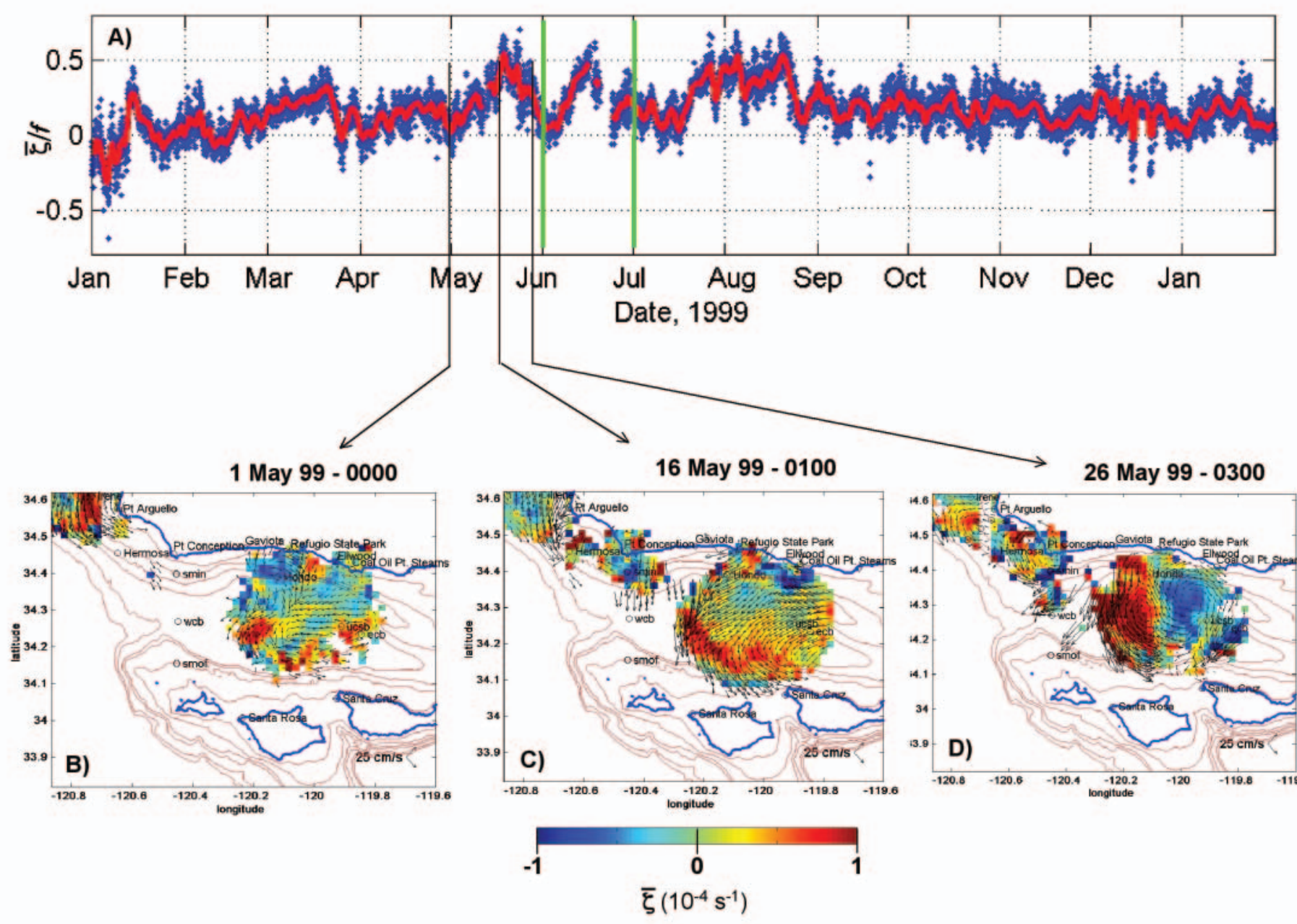

26 May $99-0300$

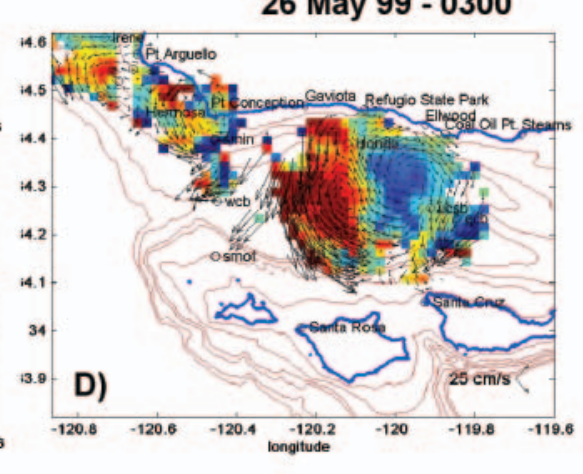

Fig. 11. (A) Time series of spatially averaged relative vorticity $\bar{\zeta}$, normalized by the Coriolis parameter $f$, in the western Santa Barbara Channel from 1 January 1999 through 31 January 2000. Surface flow field in the western Channel (B) on 1 May 1999 at 00:00 h GMT, (C) 16 May 1999 at 01:00 h GMT, (D) 26 May 1999 at 03:00 h GMT. See caption of Fig. 7 for additional explanations 
Late-stage larvae and pelagic juveniles exhibit considerable control over their speed, direction, and position in the water column (Olla et al. 1996, Leis \& Carson-Ewart 1997, 1999). Leis \& Carson-Ewart (1997) observed in situ tropical late-stage larvae frequently examining food particles, maneuvering around objects such as marine snow and jellies, and engaging in stop-go behavior, sometimes in the presence of predators. Furthermore, Stobutski \& Bellwood (1997) showed that swimming ability of late pelagic stages of a variety of tropical reef fishes (ranging in size from about 15 to $30 \mathrm{~mm}$ total length) was related to morphology and developmental stage as well as size. Laboratory studies show that larval and juvenile fishes learn to aggregate when searching for food that is patchily distributed, and after encountering a patch of prey, they remain aggregated within the patch to feed (Olla et al. 1996). Conversely, when food is dispersed, fish do not aggregate and forage more independently - this may account at least in part for the relatively low densities of fishes in areas outside of the eddy in 1998 and throughout the study region in 1999. Given the behavioral capabilities of late-stage larvae and pelagic juveniles, it is likely that many fishes do not passively concentrate in eddies but respond to some environmental factor(s) that characterize the features.

In a broader context, the very high abundance of pelagic juvenile fishes in the eddy observed in the Channel contrasts sharply with results from an oceanographic and midwater trawling survey conducted by NOAA in May-June 1998 in central California coastal waters. Pelagic juvenile catches off central California in 1998 were among the lowest since annual assessments began in 1985, a result attributed in part to the strong 1997-98 El Niño (Hayward 2000). Our sampling methods were similar to those employed by NOAA, allowing us roughly to compare our catch statistics. Our low rockfish catches north of the Channel (e.g. no rockfish were collected off Pt. Arguello and the average catch of rockfish off Pt. Purisima was 1.3 fish haul $^{-1}$ ) were similar to the average catch of 1.2 fish $\operatorname{haul}^{-1}(\mathrm{n}=92)$ off central California (S. Ralston, pers. comm.). In contrast, the average rockfish catch within the Santa Barbara Channel eddy during our survey was 462 fish haul $^{-1}$ ( $\mathrm{SE}= \pm 259, \mathrm{n}=9$ hauls). Similarly, the average catch of Pacific hake in the eddy was 3400 fish haul ${ }^{-1}(\mathrm{SE}= \pm 1300, \mathrm{n}=9)$ compared to 7.3 fish haul $^{-1}(\mathrm{n}=92)$ from the central California survey. Such differences of at least 2 orders of magnitude between mean catches off central California and in the Santa Barbara Channel eddy suggests that persistent cyclonic eddies may be important mechanisms for locally offsetting large scale declines in marine populations.

\section{Sequential events and survivorship}

Strong year-classes, separated by several years of poor recruitment, are characteristic of some fisheries including Pacific hake and rockfishes. A goal in fisheries ecology is to identify mechanisms that produce these events of strong recruitment for a species. Mullin et al. (2000) suggest that a 'sequential alignment of favorable states in several components of the environment of larvae and of juveniles' might be necessary to produce a strong year-class. These causal mechanisms, operating at spatial and temporal scales relevant to the ecology of developing fish, need not be the same from year to year, and can be ephemeral and in phase with only one of several cohorts from a spawning season.

We surmise that a particular sequence of events in 1998 led to the distributional pattern of late-larval and pelagic juvenile fishes that we observed. The spawning range of Pacific hake and many rockfishes is broad, encompassing the Channel and waters off central, northern, and southern California (Bailey et al. 1982, Moser \& Boehlert 1991). Pacific hake spawn over the continental slope between January and March but the season can extend to May. All rockfishes are ovoviviparous and many species including the ones common to our survey (shortbelly rockfish, half-banded rockfish, and squarespot rockfish) have a protracted parturition season releasing larvae during the late winter through early spring and most likely in or near the habitat where they regularly reside (Moser \& Boehlert 1991). Potentially, a number of cohorts separated in time and space can contribute to the same year-class. For the fish populations we observed, conditions may have been detrimental to early stage larvae during early 1998. February and March 1998 was a period of exceptionally intense winter storm activity along the west coast (Sakuma et al. 2000). Such intense turbulence can destroy food patches and interfere with larval feeding (Peterman \& Bradford 1987). During this time, strong downwelling was coupled with a strong countercurrent transporting warm, saline, low nutrient water northward along the coast. Productivity in coastal waters was low at this time. Survivorship of the cohorts from early in the reproductive season may have been poor.

Circulation changed dramatically in April 1998 with unusually weak upwelling persisting through May off California and Baja California (Fig. 8) (Lynn et al. 1998). Offshore advection, which generally contributes to substantial offshore dispersal of coastal species, probably declined along central California due to the weak upwelling and a strong equatorward jet near shore. It is plausible that larvae in coastal waters that survived or were spawned after the detrimental storm 
conditions could have been transported from central California through the Santa Barbara Channel in the equatorward jet. The influx of central California coastal water may have contributed to an increase in primary production in the Channel (Hayward 2000). Data from two CalCOFI surveys (23 January-14 February and 2-23 April 1998) show that coastal SST in the Santa Barbara Channel region dropped from about 15 to $13^{\circ} \mathrm{C}$, and $10 \mathrm{~m}$ chlorophyll increased from about 2 to $>7 \mathrm{mg} \mathrm{l}^{-1}$. Following this event was the establishment of closed, cyclonic circulation in the western Channel by late April. Nutrient upwelling in the cyclonic eddy may have sustained production trapped in surface waters during the protracted period of closed recirculation. The relatively high density of fishes in the eddy could then have been a consequence of high food availability and feeding success (Theilacker et al. 1996, McLaren et al. 1997). We hypothesize that fish growth was enhanced in the persistent eddy and survivorship was increased (Houde 1997, Sogard 1997) amidst poor circumstances for the populations of pelagic early life history stages elsewhere in the region.

In contrast to 1998, in the spring 1999 CalCOFI survey (1-20 April), the equatorward jet was no longer near the coast. Upwelling anomalies were particularly strong along the entire California coast in April 1999 and were among the largest ever in the over-50-year record of the upwelling index (Schwing et al. 2000). Offshore advection may have contributed to larval loss in April producing a subsequent paucity of late-stage larvae and pelagic juvenile fishes along the coast. We suggest that retention was relatively weak or absent due to propagating eddies which characterized the Channel from May 1999 through much of the summer and that significant mixing and transport occurred between these unstable features and surrounding waters resulting in the dispersal of fishes and their prey.

\section{CONCLUSIONS}

The June 1998 midwater trawling survey revealed very high concentrations of fishes in the core of a cyclonic eddy, an area of lowest dynamic height, in the western Santa Barbara Channel. Concentrations of five dominant taxa were at least an order of magnitude higher in the eddy compared with outside the eddy. Based on time series of currents and vorticity from an array of HF radars, the eddy may have retained fishes for up to $6 \mathrm{wk}$ before the June 1998 trawling survey. It is unlikely that the eddy retained the fishes longer than 6 wk because strong equatorward flow swept through the Santa Barbara Channel during most of April 1998.
A second survey in June 1999 failed to show high concentrations of fishes in the western Channel and a persistent cyclonic eddy was not found. Instead, the flow in the weeks leading up to the June 1999 survey consisted of a cyclonic turning of a broad open flow pattern that was inconsistent with retention. Compared to 1998, the mesoscale flow pattern was much more variable in 1999, when small propagating eddies produced large variations in vorticity.

Our results suggest that very large interannual abundance variations in coastal populations of larval and juvenile fishes result from changing mesoscale flow patterns. In particular, persistent cyclonic eddies, with their closed streamlines and enhanced vertical temperature gradients, may concentrate fishes through a variety of physical and behavioral mechanisms. We surmise that the development of a cohort of larval fishes may serendipitously be in phase with some sequence of mesoscale phenomena, which in this case study included the cyclonic eddy that we observed in 1998. Consequently, survivorship would be promoted within spatially and temporally limited boundaries, and a local subpopulation could contribute substantially to the population at large.

Acknowledgements. We thank F. Donahue, captain of the FV 'Gus-D' for skillful vessel operation during the trawling surveys. Assistance in the field program was provided by $\mathrm{S}$. Clark, J. Harding, E. Hessell, L. MacDonald, M. Paddack, C. Thompson, E. Beckenbach, K. McClure, D. Salazar, and C. Herren. D. Schroeder provided logistics support during the trawling surveys and helpful discussion during the analysis. We also benefited from helpful discussion with E. Dever, C. Winant, and M. Hendershott. We thank M. Love, R. Warner, S. Ralston, D. Krause, and the anonymous reviewers for their useful comments on the manuscript. The support of $\mathrm{L}$. Thorsteinson is greatly appreciated. Moored current data were provided by the Center for Coastal Studies at the Scripps Institution of Oceanography. M. Knope, E. Love, K. Mendiola, M. Moreti, M. Petueli, T. Ross, M. Simmons, E. Simons and others assisted with laboratory work. We thank E. Beckenbach and B. Emery for their analysis of the surface flow fields in 1998 and 1999. K. Lerchareonyong provided programming assistance. We thank $\mathrm{S}$. Ralston for catch statistics from NOAA's central California surveys (NMFS/ SWFSC, Santa Cruz, CA). The California Department of Fish and Game provided the midwater trawl net. Funding for the trawling surveys was provided by the Biological Resources Division of the U.S. Geological Survey under cooperative agreement 1445-CA09-95-0836. The California Artificial Reef Enhancement Program provided additional support. The Minerals Management Service and the David and Lucile Packard Foundation funded operation of the HF radars and related data analysis. The radars were obtained with funding from the W. M. Keck Foundation. We thank the California Department of Parks and Recreation, UCSB, the US Air Force, and the US Coast Guard for allowing the installation of HF radar equipment at their facilities. The views and conclusions contained in this document are those of the authors and should not be interpreted as necessarily representing the official policies, either express or implied, of the US Government. 


\section{LITERATURE CITED}

Ainley DG, Spear LB, Allen SG, Ribic CA (1996) Temporal and spatial patterns in the diet of the common murre in California waters. Condor 98:691-705

Bailey KM, Francis RC, Stevens PR (1982) The life history and fishery of Pacific whiting, Merluccius productus. Calif Coop Ocean Fish Invest Rep 23:81-98

Barrick DE, Lipa BJ (1998) Evolution of bearing determination in HF current mapping radars. Oceanography 10:72-75

Beckenbach EH, Washburn L, Salazar D, Emery BM (2000) Observations of propagating eddies in the Santa Barbara Channel. Eos Trans, Am Geophys Union, Fall Meet Suppl, Abstract OS72B-12 81

Berry FH, Perkins HC (1963) Survey of pelagic fishes of the California Current area. Fish Bull US 65:625-682

Boehlert GW, Gadomski DM, Mundy BC (1985) Vertical distribution of ichthyoplankton off the Oregon coast in spring and summer months. Fish Bull US 83:611-621

Bradford MJ (1992) Precision of recruitment predictions from early life stages of marine fishes. Fish Bull US 90:439-453

Brothers EB, Williams DM, Sale PF (1983) Length of larval life in twelve families of fishes at 'One Tree Lagoon', Great Barrier Reef, Australia. Mar Biol 76:319-324

Chambers RC, Trippel EA, eds. (1997) Early life history and recruitment in fish populations. Chapman and Hall, London

Connolly SR, Roughgarden J (1999) Increased recruitment of northeast Pacific barnacles during the 1997 El Niño. Limnol Oceanogr 44:466-469

Cushing DH (1974) The possible density-dependence of larval mortality and adult mortality in fishes. In: Blaxter JHS (ed) The early life history of fish. Springer-Verlag, Berlin, p 103-111

Dever EP, Hendershott MC, Winant CD (1998) Statistical aspects of surface drifter observations of circulation in the Santa Barbara Channel. J Geophys Res-Oceans 103: 24781-24797

Dickey-Collas M, Brown J, Fernand L, Hill AE, Hornsburgh KJ, Garvine RW (1997) Does the western Irish Sea gyre influence the distribution of pelagic juvenile fish? J Fish Biol 51:206-229

Golden Software (1999) Surfer, Version 7. Golden, CO

Graber HC, Haus BK, Chapman RD, Shay LK (1997) HF radar comparison with moored estimates of current speed and direction: expected differences and implications. J Geophys Res 102:18749-18766

Gurgel KW (1994) Shipborne measurement of surface current fields by HF radar. L'Onde Electrique 74:54-59

Hare JA, Cowen RK (1996) Transport mechanisms of larval and pelagic juvenile bluefish (Pomatomus saltatrix) from South Atlantic Bight spawning grounds to mid-Atlantic Bight nursery habitats. Limnol Oceanogr 41:1264-1280

Harms S, Winant CD (1998) Characteristic patterns of the circulation in the Santa Barbara Channel. J Geophys Res-Oceans 103:3041-3065

Hayward TL (2000) El Niño 1997-98 in the coastal waters of Southern California: A timeline of events. Calif Coop Ocean Fish Invest Rep 41:98-116

Hayward TL, Mantyla AW (1990) Physical, chemical and biological structure of a coastal eddy near Cape Mendocino. J Mar Res 48:825-850

Hayward TL, Baumgartner TR, Checkley DM, Durazo R and 8 others (1999) The state of the California Current in 1998-1999: Transition to cool-water conditions. Calif Coop Ocean Fish Invest Rep 40:29-62

Hickey BM (1998) Coastal oceanography of western North
America from the tip of Baja California to Vancouver Island. In: Robinson AR, Brink KH (eds) The sea: the global coastal ocean: regional studies and syntheses. John Wiley, New York, p 345-393

Hjort J (1914) Fluctuations in the great fisheries of Northern Europe viewed in light of biological research. Rapp P-V Réun Cons Int Explor Mer 20

Houde ED (1997) Patterns and trends in larval-stage growth and mortality of teleost fish. J Fish Biol 51:52-83

Huntley ME, Zhou M, Nordhausen W (1995) Mesoscale distribution of zooplankton in the California Current in late spring, observed by optical plankton counter. J Mar Res 53:647-674

Huntley ME, González A, Zhu M, Irigoien X (2000) Zooplankton dynamics in a mesoscale eddy-jet system off California. Mar Ecol Prog Ser 201:165-178

Kahru M, Mitchell BG (2000) Influence of the 1997-98 El Niño on the surface chlorophyll in the California Current. Geophys Res Lett 27:2937-2940

Kelly KA (1985) The influence of winds and topography on the sea surface temperature patterns over the northern California slope. J Geophys Res-Oceans 90:11783-11798

Kimura S, Nakata H, Okazaki Y (2000) Biological production in meso-scale eddies caused by frontal disturbances of the Kuroshio Extension. ICES J Mar Sci 57:133-142

Lasker R (1981) Factors contributing to variable recruitment of the northern anchovy (Engraulis mordax) in the California Current: contrasting years 1975-1978. Rapp P-V Réun Cons Int Explor Mer 178:375-388

Leis JM, Carson-Ewart BM (1997) In situ swimming speeds of the late pelagic larvae of some Indo-Pacific coral-reef fishes. Mar Ecol Prog Ser 159:165-174

Leis JM, Carson-Ewart BM (1999) In situ swimming and settlement behaviour of larvae of an Indo-Pacific coralreef fish, the coral trout Plectropomus leopardus (Pisces: Serranidae). Mar Biol 134:51-64

Lenarz WH, Larson RJ, Ralston S (1991) Depth distributions of late larvae and pelagic juveniles of some fishes of the California Current. Calif Coop Ocean Fish Invest Rep 32:41-46

Lenarz WH, Ventresca DA, Graham WM, Schwing FB, Chavez F (1995) Explorations of El Niño events and associated biological population dynamics off central California. Calif Coop Ocean Fish Invest Rep 36:106-119

Limouzy-Paris CB, Graber HC, Jones DL, Ropke AW, Richards WJ (1997) Translocation of larval coral reef fishes via sub-mesoscale spin-off eddies from the Florida Current. Bull Mar Sci 60:966-983

Logerwell EA, Smith PE (2001) Mesoscale eddies and survival of late stage Pacific sardine (Sardinops sagax) larvae. Fish Oceanogr 10:13-25

Love M, Nishimoto M, Schroeder D, Caselle J (1999) The ecological role of natural reefs and oil and gas production platforms on rocky reef fishes in southern California: final interim report. : U. S. Department of the Interior. Report nr USGS/BRD/CR-1999-0007, OSC Study MMS 99-0015

Malkiel E, Alquaddoomi O, Katz J (1999) Measurements of plankton distribution in the ocean using submersible holography. Meas Sci Technol 10:1142-1152

McFarlane GA, King JR, Beamish RJ (2000) Have there been recent changes in climate? Ask the fish. Prog Oceanogr 47:147-169

McGowan JA, Cayan DR, Dorman LM (1998) Climate-ocean variability and ecosystem response in the northeast Pacific. Science 281:210-217

Moser HG (1996) The early stages of fishes in the California Current region. California Cooperative Oceanic Fisheries 
Investigations, Atlas No. 33. La Jolla, LA

Moser HG, Boehlert GW (1991) Ecology of pelagic larvae and juveniles of the genus Sebastes. Environ Biol Fishes 30:203-224

Moser HG, Charter RL, Smith PE, Ambrose DA, Charter SR, Meyer CA, Sandknop EM, Watson W (1993) Distributional atlas of fish larvae and eggs in the California Current region: Taxa with 1000 or more total larvae, 1951-1984. California Cooperative Fisheries Investigations Atlas No. 31. La Jolla, LA

Mullin MM, Goetze E, Beaulieu SE, Lasker JM (2000) Comparisons within and between years resulting in contrasting recruitment of Pacific hake (Merluccius productus) in the California Current System. Can J Fish Aquat Sci 57: 1434-1447

Neilson JD, Perry RI (1990) Diel vertical migrations of marine fishes: an obligate or facultative process? Adv Mar Biol 26:115-168

Olla BL, Davis MW, Ryer CH, Sogard SM (1996) Behavioural determinants of distribution and survival in early stages of walleye pollock, Theragra chalcogramma: a synthesis of experimental studies. Fish Oceanogr 5:167-178

Owen RW (1980) Eddies of the California Current System: Physical and ecological characteristics. In: Power DM (ed) The California Islands: proceedings of a multidisciplinary symposium. Santa Barbara Museum of Natural History, Santa Barbara, CA, p 237-263

Paduan JD, Rosenfeld LK (1996) Remotely sensed surface currents in Monterey Bay from shore-based HF radar (Coastal Ocean Dynamics Application Radar). J Geophys Res 101:20669-20686

Parrish RH, Nelson CS, Bakun A (1981) Transport mechanisms and reproductive success of fishes in the California Current. Biol Oceanogr 1:175-203

Peterman RM, Bradford MJ (1987) Wind speed and mortality rate of a marine fish, the northern anchovy (Engraulis mordax). Science 235:354-356

Peterman RM, Bradford MJ, Lo NCH, Methot RD (1988) Contribution of early life stages to interannual variability in recruitment of northern anchovy (Engraulis mordax). Can J Fish Aquat Sci 45:8-16

Ralston S, Howard DF (1995) On the development of yearclass strength and cohort variability in two northern California rockfishes. Fish Bull US 93:710-720

Sakuma KM, Ralston S (1995) Distributional patterns of late larval groundfish off central California in relation to hydrographic features during 1992 and 1993. Calif Coop Ocean Fish Invest Rep 36:179-192

Sakuma KM, Ralston S (1997) Vertical and horizontal distribution of juvenile Pacific whiting (Merluccius productus) in relation to hydrography off California. Calif Coop Ocean Fish Invest Rep 38:137-146

Sakuma KM, Ralston S, Roberts DA (1999) Diel vertical distribution of postflexion larval Citharichthys spp. and Sebastes spp. off central California. Fish Oceanogr 8:68-76

Editorial responsibility: Kenneth Sherman (Contributing Editor), Narragansett, Rhode Island, USA
Sakuma KM, Schwing FB, Pickett MH, Roberts D, Ralston S (2000) The physical oceanography off the California coast during May-June 1998: A summary of CTD data from pelagic juvenile rockfish surveys. US Department of Commerce. Report nr NOAA-TM-NMFS-SWFSC-297

Sanchez F, Gil J (2000) Hydrographic mesoscale structures and Poleward Current as a determinant of hake (Merluccius merluccius) recruitment in southern Bay of Biscay. ICES J Mar Sci 57:152-170

Schwing FB, Husby DM, Garfield N, Tracy DE (1991) Mesoscale oceanic response to wind events off central California in Spring 1989-CTD Surveys and AVHRR imagery. Calif Coop Ocean Fish Invest Rep 32:47-62

Schwing FB, Moore CS, Ralston S, Sakuma KM (2000) Record coastal upwelling in the California Current in 1999. Calif Coop Ocean Fish Invest Rep 41:148-160

Shay LK, Lentz SJ, Graber HC, Haus BK (1998) Current structure variations detected by high-frequency radar and vector-measuring current meters. J Atmos Ocean Tech 15:237-256

Siegel DA, McGillicuddy DA, Fields EA (1999) Mesoscale eddies, satellite altimetry, and new production in the Sargasso Sea. J Geophys Res 104:13359-13379

Sissenwine MP (1984) Why do fish populations vary? In: May RM (ed) Exploitation in marine communities: report of the Dahlem Workshop on exploitation of marine communities. Springer-Verlag, Berlin, p 59-94

Sogard SM (1997) Size-selective mortality in the juvenile stage of teleost fishes: a review. Bull Mar Sci 60: 1129-1157

SPSS (1999) SPSS for Windows. Version 10.0.5, Chicago, IL

Stobutski IC, Bellwood DR (1997) Sustained swimming abilities of the late pelagic stages of coral reef fishes. Mar Ecol Prog Ser 149:35-41

Strub PT, Kosro PM, Huyer A, collaborators C (1991) The nature of the cold filaments in the California current system. J Geophys Res 96:14743-14768

Theilacker GH, Bailey KM, Canino MF, Porter SM (1996) Variations in larval walleye pollock feeding and condition: a synthesis. Fish Oceanogr 5:112-123

Vastano AC, Incze LS, Schumacher JD (1992) Observations and analysis of fishery processes: larval pollock at Shelikof Strait, Alaska. Fish Oceanogr 1:20-31

Washburn L, Nishimoto MM, Emery BM (2000) Surface circulation near Pt. Conception, California: a mechanism for larval retention? Eos Transactions, Am Geophys Union Fall Meet Suppl, Abstract OS71E-03 81

Winant CD, Alden DJ, Dever EP, Edwards KA, Hendershott MC (1999) Near-surface trajectories off central and southern California. J Geophys Res-Oceans 104:15713-15726

Zimmerman RA, Biggs DC (1999) Patterns of distribution of sound-scattering zooplankton in warm- and cold-core eddies in the Gulf of Mexico, from a narrowband acoustic Doppler current profiler survey. J Geophys Res-Oceans 104:5251-5262

Submitted: December 12, 2001; Accepted: June 1, 2002

Proofs received from author(s): September 10, 2002 